EstAg 33 (1998) 525-578

\title{
EL EPISCOPADO. CENTRO NEURÁLGICO EN LOS CAMINOS DE LA UNIDAD
}

El drama de la desunión de las iglesias cristianas sigue golpeando las conciencias de las mismas. Varias son las razones que están tras de esta realidad negativa. La voluntad del Señor, expresada de forma solemne en su llamada oración sacerdotal, de que todos los creyentes en él fueran uno a semejanza de la comunión que hay entre Él y el Padre, es, sin lugar a dudas, la fuente más abundosa del remordimiento eclesial. "No ruego sólo por éstos, sino también por aquéllos que, por medio de su palabra, creerán en mí. Que todos sean uno. Como tú, Padre, en mí y yo en ti, que ellos sean uno en nosotros, para que el mundo crea que tú me has enviado". (Jn 17, 20-21).

Se aprecia en el texto bíblico una preocupación intensa por el tema de la unidad, saliendo así al paso del peligro de la desunión. Peligro que se intenta evitar, a fin de no caer en los graves inconvenientes que ello acarrearía. Entre los cuales está nada menos y nada más que el reconocimiento o no del envío del mismo Jesús por el Padre.

El texto evangélico, que tiene validez para la iglesia de todos los tiempos, quiere ser un remedio eficaz para aquellas comunidades que nacieron bajo el influjo de la persona y del testimonio del «discípulo amado». Dichas comunidades padecían en aquel entonces una fuerte división. Necesitaban, por lo mismo, un buen antídoto. Y la oración, puesta en boca de Jesús, quiere ser una llamada urgente a la unidad, so pena de invalidar la fuerza de su testimonio a favor de Jesús.

Las iglesias posteriores han desoído en parte el mensaje del Señor. Digo "en parte", porque hay que reconocer que es mucho más lo que las une que lo que las separa. Al tiempo que hay que decir que lo que las une no sólo afecta al número, sino y principalmente a la calidad. Todas giran alrededor del misterio trinitario y de la persona adorable del Señor, Dios y salvador. Todas rezan el mismo credo. $\mathrm{Y}$ todas quieren transmitir el núcleo del evangelio, que no es otro que la persona del Señor Jesús. 
Resaltado esto con gozo, es necesario no dejar de lado, aunque se haga con pena, que la unión entre las iglesias no es completa. Existe, por lo mismo, desunión. Y la desunión, acogiendo el mensaje de la oración del Señor, compromete, por lo mismo, la misión de las mimas. Las iglesias están para llevar a la fe en Cristo a quienes no la tienen o confirmar la fe en Cristo a quienes ya la tienen. Pues bien, conforme a las palabras del Señor, su misión queda gravemente tocada por la desunión.

Ésta es, con toda verdad, la segunda de las graves razones que amargan la conciencia negativa de las iglesias. Ellas saben que su mensaje no puede encontrar eco o, al menos, suficiente eco en las gentes por estar desunidas. Y captan, es imposible soslayar el impacto, la contradicción que hay entre la confesión de una iglesia una, así se hace en el credo, y la realidad de una unidad rota.

Constatado el hecho de la desunión, por cierto parcial, de las iglesias, y sin olvidar el tema a tratar, tal y como queda reflejado en el título, me permito, en obsequio a la claridad y a la comprensión por el lector, dar un anticipo del tema. Por usar una imagen del cine, se trata de un avance de lo que va a ofrecer la película, que, por supuesto, en este caso es el cuerpo del artículo.Tal avance viene a ser un resumen del contenido que refleja el artículo. He dicho resumen. Y es verdad. Pero hay más. Es también una especie de aurora que preludia la aparición de un sol brillante, cuyos rayos potentes y luminosos ayudan a ver con claridad el tema de suyo complejo del Ministerio, en general, y del episcopado, en particular. Comienzo ya con el avance.

Uno de los campos en el que aparece con fuertes rasgos la desunión eclesial es el campo del Ministerio'. Es de recibo común que las iglesias tienen figuras ministeriales diversas. En algunas de ellas, por cierto las más significativas, existe la figura del obispo como figura cumbre. En otras, bastantes por cierto, no existe tal figura, aunque se den figuras que, de alguna manera, pueden equipararse a la figura del obispo.

Lo más grave es que se dan sobre el tema visiones teológicas casi encontradas. Hay consenso en ver el Ministerio como realidad que pertenece al ser de la iglesia. E. Schillebeeckx lo expresa muy bien. "La segunda conclusión es que, según la Escritura, el ministerio eclesial pertenece a la esencia de la iglesia estructurada Apostólicamente y, por tanto, a la esencia de la iglesia como «iglesia de Cristo»"2. El problema se plantea no sólo por lo que mira a

1. Escribo con mayúscula Ministerio, cuando se trata del Ministerio especial y para distinguirlo del ministerio de toda la iglesia, que lo escribo con minúscula.

2. La misión de la iglesia, Sígueme, Salamanca, 1971, p 489 
las figuras concretas, sino, y hay que decir que de forma intensa, por lo que respecta a la teología acerca del Ministerio. En este campo concreto, lo veremos pronto, la teología católica o de tipo católico y la protestante han estado durante largos años muy enfrentadas.

Últimamente las cosas han cambiado mucho. Se debe particularmente a los avances que en este campo concreto han llevado a cabo los estudios ecuménicos. Véase, como ejemplo, unas palabras de un documento elaborado por los Institutos ecuménicos alemanes. "Dado que para un mutuo reconocimiento de los ministerios no existe ya ningún impedimento teológico decisivo, se ha superado un obstáculo para la plena comunidad en la Cena del Señor. Allí donde se dé una fe común en la presencia de Jesús en la Eucaristía es posible la mutua admisión a la Santa Cena"3. Soy consciente que este documento ha sido muy contestado y no cuenta con la aprobación de la Conferencia Episcopal Alemana. A pesar de todo, y teniendo en cuenta la competencia de quienes lo han elaborado, es un exponente alto de que se ha dado un cambio en el tema. Y un cambio importante. Lo reflejan no sólo el documento citado, sino todos los documentos ecuménicos que han tratado el tema del Ministerio.

Todas las iglesias, lo recordaba líneas antes, aceptan la necesidad del Ministerio como realidad eclesial. En esto hay un consenso absoluto. Sin embargo, dicho consenso no se ha dado y todavía no se da, a pesar de los avances en el tema, por lo que mira tanto a la teología del Ministerio en sí, como a las figuras que lo encarnan. Por simplificar un poco el problema, se puede hablar de dos corrientes principales. Una es la corriente catolizante. Otra, la corriente de la Reforma.

La primera tiende a expresar su teología del Ministerio de una forma simplificada. Su fórmula es Cristo-Ministros-fieles. El Ministerio tiene así su fuente directa y próxima en el mismo Cristo. Los ministros son medios directos e imprescindibles en la relación de Cristo-cabeza y sus miembros, en la línea trazada por el P. Congar, cuando dice: "El esquema lineal (CristoSacerdocio-fieles) (conlleva) el peligro de hacer del Sacerdocio jerárquico una mediación que supondría un pueblo menor, impotente y pasivo"4. Los ministros reciben una configuración de superioridad y de lejanía. Se hallan como enfrentados, (gegenüber, dicen los alemanes), al resto de la comunidad. Tienen unos poderes, (fijarse en la palabra), de los que carecen los demás

3. Reforma y reconocimiento de los ministerios. Seminarios 57-58, Salamanca, 1975, nr.23.

4. Ministerios y comunión eclesial, FAX, Madrid,1973, p. 20. 
miembros de la iglesia. Y, como son poderes, los pueden ejercer a su arbitrio, si viene al caso.

Haciendo una valoración de esta teología del Ministerio, se puede decir, sin ignorar sus puntos positivos, que es una teología del mismo muy reduccionista, porque no refleja ni la rica variedad de Ministerios que hubo en los orígenes, ni la evolución que se dio hasta fijar los Ministerios que hoy existen en la iglesia. Además corre el grave peligro de ofrecer una teología del Ministerio en clave de poder. Cierto que Cristo es la cabeza de la iglesia y que tiene que ver en la aparición de quienes lo representan como ministros. Mas, una vez afirmado el dato, queda la tarea de averiguar el modo en que se ha producido. Si nos atenemos a la información que da el Nuevo Testamento, parece imposible afirmar que, aparte el Ministerio apostólico, que es fundante de la iglesia, los otros Ministerios tengan origen en una voluntad expresa y directa de Cristo. Todo apunta a que han ido apareciendo, eso sí bajo el impulso del Espíritu Santo, que es el Espíritu de Cristo, motor vital de la iglesia, a consecuencia de situaciones eclesiales nuevas y al aliento de situaciones territoriales concretas. Me fijo en dos Ministerios significativos entonces y ahora, dejando a un lado por el momento su escala de importancia. Los presbíteros aparecen en lugares en donde tiene una presencia fuerte la cultura judía. Todos sabemos que era una institución muy querida por los judíos. Los episcopoi, uso el original griego para evitar el inconveniente de equipararlo sin más con el obispo actual, aparecen en lugares en que se da una presencia más firme de la cultura helénico-romana. Ambos Ministerios se mezclan hasta el extremo que hay un tiempo en el que es preciso hablar de episcopoipresbiteroi, indicando que sus nombres y sus competencias son intercambiables.

Lo definitivo de todo esto es que no se puede hablar de una voluntad expresa y directa del Señor en el tema de los Ministerios. De haber existido, hubiera tenido repercusión directa en la configuración ministerial de las iglesias apostólicas.

La segunda, la mantenida por la Reforma, hace entrar en acción a la comunidad, asistida y movida por el Espíritu, a la hora de hablar del Ministerio y de los Ministros. La comunidad, pueblo de Dios, tiene su ministerio y el Ministerio sólo es inteligible desde el ministerio eclesial. Un espléndido párrafo del Grupo teológico luterano-católico de Estados Unidos refleja y recalca el matiz. "La iglesia tiene, por consiguiente, la misión de proclamar el evangelio a todos, creyentes y no creyentes. Esta misión o servicio de toda la iglesia es llamada ministerio (diakonía). En el curso de esta declaración empleamos el término ministerio (con minúscula, con y sin artículo defi- 
nido) en este sentido. El ministerio de la iglesia entendido de esta manera se distinguirá del (o un) Ministerio, una forma particular de servicio -un orden específico, función o carisma- que se encuentra dentro y en beneficio de la iglesia de Cristo en su misión hacia el mundo. El término Ministro empleado en este documento se refiere a la persona a quien ha sido confiado este Ministerio. Estamos convencidos de que el Ministerio especial no puede ser discutido aparte, sino en el contexto del ministerio de todo el pueblo de Dios"5.

La teología del Ministerio, que subyace a esta forma de ver las cosas, parece que responde mejor a la misma razón de ser del Ministerio y a los datos que ofrece la investigación moderna. El ministro es en esta visión un miembro de la comunidad que no actúa por su cuenta, sino como quien ha recibido una misión. No hay aquí categorías de poder. Y la misión no se puede ejercer autárquicamente.

Dos citas de afamados teólogos católicos apoyan esa forma de ver las cosas. El P. Congar dice: "La entrada por la puerta y el concepto de comunidad sería más satisfactoria. Huiríamos así de dos concepciones desafortunadas: igualmente desafortunadas, además. No sería el esquema lineal (CristoSacerdocio-Fieles), con el peligro de hacer del Sacerdocio jerárquico una mediación que supondría un pueblo menor, impotente y pasivo. No sería una especie de democratismo que los Protestantes no profesan, aunque a veces algunas expresiones suyas podrían inquietar («devolución», por ejemplo): porque no hacen de los ministros puros delegados de la comunidad; sostienen que Dios ha querido y, en este sentido, instituido ministerios, pero de manera global, de suerte que no se puede deducir del Nuevo Testamento un tipo de organización que se impusiera iure divino de forma absolutamente normativa. Son las iglesias las que, por su disciplina, organizan estos ministerios, teniendo en cuenta lo que la Escritura puede decir a ese propósito (...)"6.

E. Schillebeeckx es el segundo teólogo católico que pone su guinda, por cierto bien grande y roja, sobre el tema. "Los actuales ministerios eclesiales (episcopado, presbiterado, diaconado) no fueron instituidos directamente por Jesús. Los análisis históricos demuestran que ciertos modelos preexistentes en el mundo judío y helenista, así como las exigencias de la situación histórica de la iglesia, han influido en la estructura concreta del gobierno de las comunidades. Pensando sociológicamente, es natural que ese grupo social que es la iglesia tenga que tener servicios ministeriales. El proceso sociológi-

5. Eucaristía y ministerio. Seminarios 57-58, Salamanca, 1975, nr.9

6. Ministerios y comunión eclesial, FAX, Madrid, 1973, p. 20 
co que desembocó dentro de la iglesia en el episcopado, presbiterado y diaconado, a partir de otros ministerios mucho más numerosos en su origen (de los que muchos desaparecieron o se reagruparon con otros), se interpreta legítimamente, por motivos eclesiológicos -la iglesia es, en efecto, el templo del Espíritu Santo-, como la obra misma del Espíritu Santo, el Espíritu de Cristo glorificado. Así, pues, aunque su origen no se remonte a una institución por el Jesús histórico, esos ministerios son, en virtud del carácter pneumático de la iglesia estructurada Apostólicamente, el fruto del Espíritu y no el resultado de un proceso sociológico. En este sentido se puede afirmar que los ministerios eclesiales son de «derecho divino». Pero ese «derecho divino» debe comprenderse de tal forma que suponga y haga posible un desarrollo histórico de las formas y de la distribución de las competencias ministeriales. Por tanto, es posible una evolución de las estructuras, no sólo en el pasado, como lo ha demostrado la historia, sino también en el futuro, al menos en la medida en que la iglesia puede reconocer en dicha evolución la acción del Espíritu Santo. Teniendo en cuenta lo que hay de único en el Apostolado, está claro que el gobierno Apostólico de la iglesia primitiva tiene que servir de modelo a la hora de buscar un criterio que permita reconocer el carácter pneumático de la reestructuración propuesta"7.

Uno y otro texto portan un mensaje digno de tenerse en cuenta. El P. Congar deja bien claro que el camino adecuado para situar el Ministerio es el de la comunidad.Y se entiende con facilidad. El grave peligro del Ministerio se encuentra en la absolutización del mismo. Aislarlo de la comunidad significa darle consistencia en sí mismo. Y, con ello, lo único que se consigue es justificar algo que sólo tiene justificación en razón del servicio. El Ministerio está para servir. Y el servicio mira siempre a una realidad. Se sirve a algo. En nuestro caso, a una comunidad cristiana.

El texto de Schillebeeckx es también muy significativo. En el tema del Ministerio se tiende en algunas iglesias a ver voluntades expresas de Cristo. $\mathrm{Y}$, con ello, a sacralizar tanto el mismo Ministerio, como a las personas que lo detectan. Esta tendencia se traduce siempre en actitudes inmovilistas. Modelos de Ministerio y de ministros pierden así la razón de su existencia, que no es otra que estar al servicio de la comunidad. Se bloquea también la posibilidad de optar por un cambio, cuando tanto el modelo de Ministerio, como las personas que lo detectan no responden ya a sus cometidos. Se desplaza, por lo mismo, el punto de mira. Lo que interesa es, por ejemplo, que haya obispos, Ministerio cumbre, aunque tales obispos no cumplan con la

7. La misión de la iglesia, Sígueme, Salamanca, 1971, pgs. 488-489 
tarea de la episcopé. Todo ello bajo la capa de un ius divinum intocable, inmutable. Y, por ello, trans-histórico. Dicho en forma un tanto poética: prendido de la estrellas.

Tanto lo que dice Congar, como lo que dice Schillebeeckx refleja las conquistas que en el campo del Ministerio se han hecho últimamente. Conquistas que, sin inclinar la balanza totalmente de un lado o de otro, han hecho posible acercamientos muy sustanciales. De parte de la corriente católica se ha pulido grandemente su visión del Ministerio, dando entrada en la misma a la acción del Espíritu, Espíritu, por cierto de Cristo, y superando la tendencia de acudir sin más a la voluntad expresa de Cristo. También se ha dado mayor importancia al carácter eclesiológico del Ministerio. El Ministro no es un autócrata que puede obrar por sí mismo. Ello no ha supuesto ninguna desvalorización de su Ministerio principal, que es el episcopado. De parte de la corriente protestante se ha matizado enormemente la relación de dependencia de los ministros de la iglesia. Los ministros no son meros delegados de la iglesia. Representan a Cristo y ello hace que tengan sobre la comunidad una exousía, un cierto poder, necesaria para poder cumplir con su misión bajo el impulso del Espíritu. Ello les ha llevado a descubrir la importancia del episcopado como Ministerio clave de unas iglesias reconciliadas.

Ante esta nueva realidad, ante este nuevo talante, no extraña que el Documento de Accra, elaborado por la Comisión «FE Y CONSTITUCIÓN» del C.E.I, pueda escribir: "La pluralidad de culturas eclesiales y estructuras del ministerio no disminuye sin embargo en nada la realidad de ministerio único descubierto en Cristo y constituido por el Espíritu Santo en la misión dada a los apóstoles. Entre las diferentes estructuras del ministerio, es la forma del triple ministerio -obispo, presbítero y diácono- el que predomina. Sin embargo, sería falso excluir otras formas de ministerio que se encuentran en las iglesias. Dentro de una misma comunión de fe es posible tener, codo con codo, diferentes estilos de vida eclesial y de estructuras del ministerio, sin que una de ellas deba servir de modelo a las otras (...)

La importancia del episcopado histórico no es disminuida por los descubrimientos arriba mencionados. Por el contrario, esta nueva comprensión ha permitido a las iglesias, que no habían conservado el episcopado histórico, apreciarlo como signo de la continuidad y de la unidad de la iglesia. Cada vez un mayor número de iglesias, que comprenden a las que participan en las negociaciones para la unión, se declaran dispuestas a ver en el episcopado un signo preeminente de la sucesión apostólica de toda la iglesia en la fe, la vida y la doctrina; este hecho lo consideran como una realidad hacia la que hay que tender en el caso de que no existiera. La única cosa que se considera 
incompatible con la investigación histórica y teológica es la idea según la cual la sucesión episcopal sería idéntica a la apostolicidad de toda la iglesia y la contendría"8.

Estos espléndidos párrafos, amén de lo que ya ha quedado reseñado, están en la base de las reflexiones que voy a hacer sobre un Ministerio tan significativo para la unión de las iglesias. Para quienes estamos enamorados del movimiento ecuménico en su afán por eliminar obstáculos en el camino de la unión de las iglesias, es una gran satisfacción poder iluminar campos tan complejos como es el campo del Ministerio. Campo, por lo demás, tan sacralizado en algunas iglesias que produce miedo el intento de invadir su sagrado recinto y conseguir así una cierta des-mitificación absolutamente necesaria, si se quiere avanzar hacia la meta de la unidad de las iglesias.

Ha llegado el momento de avanzar los apartados que van a hilvanar el tejido del artículo. Sin intentar ser exhaustivo, ellos pueden ser éstos:

\section{1.- Breve, pero liberador, recorrido por el Nuevo Testamento}

\section{2.- El Ministerio en el ministerio}

\section{3.- Importancia de la eclesiología local en el tema}

\section{4.- El episcopado como Ministerio universal}

\section{1.- Breve, pero liberador, recorrido por el Nuevo Testamento}

Adentrarse en el Nuevo Testamento constituye una necesidad ineludible de cualquier tarea teológica. El concilio Vaticano II dice al respecto: "Fórmense con diligencia especial los alumnos en el estudio de la Sagrada Escritura, que debe ser como el alma de toda teología"9. La frase es paradigmática. Todo trabajo, que se precie de ser teológico, debe hundir sus raíces en la Biblia.

Éste es mi propósito, no sin antes añadir que voy a intentar hacerlo con la mayor objetividad posible. A veces se oye el reproche que uno halla en la Biblia lo que uno ya tiene preconcebido. Y, por ello, se hace decir a la Biblia lo que uno quiere. El peligro existe. Y ciertamente hay que reconocer que

8. Comisión "Fe y CONSTitución” DEL C.E.I. Documento de Acrra. Seminarios 57-58, Salamanca, 1975 , nrs. 25 y 37.

9. OT. $16 \mathrm{~b}$. 
nadie se acerca a la lectura de un libro con la mente en blanco. Los pre-juicios o, si se quiere, la pre-comprensión, palabra que aclara el aspecto positivo de la palabra pre-juicios, es un elemento de partida indispensable. Mas ello no comporta que se camufle el mensaje que tiene un texto, siempre y cuando el estudioso mantenga una actitud de respeto y de búsqueda objetiva. Voy a intentar ser fiel a este compromiso.

Quien se adentre en la lectura del Nuevo Testamento descubrirá, sin mayor esfuerzo, que en el tema del Ministerio se da una enorme variedad. Al principio, y ello se entiende fácilmente, la organización es mínima. El peso de esta responsabilidad cae sobre aquéllos que habían acompañado al Señor durante su periplo terreno. Al frente de ese grupo, los Doce, recompuesto tras la salida de Judas Iscariote con la persona de Matías, se halla Pedro. Pedro hace las veces de líder o corifeo dentro del grupo. El es quien dirige la palabra a la multitud, anunciándoles la Buena Noticia de Jesús, crucificado, muerto, resucitado y constituido en gloria Señor y Juez de vivos y muertos. El es también quien propone a sus oyentes la conversión y acepta la entrada en la comunidad de quienes se sienten interpelados por la predicación de la Buena Noticia.

Cuando hay un conflicto, es el caso de las viudas narrado en el capítulo 6 de los Hechos, los Doce, seguramente dirigidos por Pedro, marcan el camino a seguir. La creación de aquellos que deben atender a las viudas, todavía no se puede hablar de lo que técnicamente va a significar el Ministerio del diaconado, tiene un valor extraordinario para el tema del Ministerio. Se crea, como se puede ver, un Ministerio nuevo. Y ello en base a que ha aparecido una situación nueva. La iglesia no se siente constreñida en su acción. Y no se siente así, porque sobre el tema no tiene ningún mandato concreto del Señor. Dicho de otra forma: la iglesia crea un Ministerio nuevo, porque se halla ante una situación nueva. Es digno también de reseñar el camino seguido. Los Doce no se toman el asunto por su cuenta. Implican a la comunidad, que es la que va a proponer a los que van a recibir tal Ministerio. Por último, aparece la presencia del Espíritu, invocada por la oración y manifestada por la imposición de manos. El cuadro, como se ve, es perfecto. Y ofrece un camino válido a seguir.

Pedro es quien, de forma misteriosa, da el paso para abrir el mensaje cristiano a los paganos. El dato se narra con lujo de detalles en los Hechos de los Apóstoles, capítulo 10. El paso, dado por Pedro bajo el impulso del Espíritu Santo, levanta los celos de aquellos judíos que, ciertamente convertidos a la causa cristiana, seguían todavía bajo el impacto de la ley mosaica. Llaman, por así decirlo, al orden a Pedro. Le acusan de cosas que un judío no debía 
hacer en base a la Ley mosaica. Pedro, tras escuchar las acusaciones, explica los hechos por su orden y la tormenta se calma, de momento.

Digo de momento, porque la cosa vuelve a entrar en acción, sobre todo a partir de la obra misionera de Pablo y Bernabé. Muchos judíos convertidos siguen en sus trece. Hay que circuncidar a los convertidos del paganismo y hacerles guardar la ley de Moisés, si quieren conseguir la salvación. Para solucionar el problema creado por estos discípulos de origen judío, se convoca el llamado concilio de Jerusalén. Es la última vez que los Hechos nos hablan de Pedro. Después desaparece y todo lo que de él se dice ya no tiene más apoyo que el de la tradición.

Si nos fijamos en la composición del concilio, notaremos cosas muy dignas de tenerse en cuenta en el tema del Ministerio. En este concilio aparece la figura de Santiago, el hermano del Señor, no identificable con ninguno de los Doce, y aparecen los ancianos o presbíteros, institución de raigambre judía. En estos precisos momentos la iglesia de Jerusalén, la iglesia madre, sin paliativos, está ya gobernada por Santiago, el hermano del Señor, a quien asisten unos ancianos. De Pedro, el líder de la comunidad jerosolimitana nacida al calor de Pentecostés y hogar en donde se cuece el primitivo mensaje cristiano, los Hechos de los Apóstoles sólo narran su intervención en la Asamblea, para luego mantener un silencio total. La comunidad de Jerusalén ha cambiado de líder. También se ha organizado en coherencia a la cultura judía, en cuyo seno sigue viviendo. Junto a Santiago aparecen los ancianos, institución muy cara a los judíos, que le ayudan en el gobierno de la iglesia de Jerusalén. Es un buen ejemplo de como van evolucionando las cosas, a medida que se retrasa la vuelta del Señor y la iglesia va tomando conciencia de su permanencia en el tiempo. Y también es un buen ejemplo de la flexibilidad con que hay que mirar todo lo referente al tema del Ministerio.

Hablar de «flexibilidad» no significa dejar todo el tema del Ministerio a expensas de la mera evolución histórica. Se trata sencillamente de desbloquear un tema que el exceso de dogmatismo ha petrificado hasta el extremo de convertirlo en una de las fuentes más caudalosas de separación entre las iglesias. Un equilibrado texto del teólogo Schillebeeckx precisa muy bien el alcance de lo que acabo de afirmar. Tras recordar el cambio eclesiológico llevado a cabo por el concilio Vaticano II, viendo a la iglesia como nuevo pueblo de Dios y a los ministros dentro y no fuera de ese mismo pueblo y a su servicio, añade: "No obstante, la importancia que se le da al pueblo de Dios -reacción afortunada contra una tradición que identificaba poco más o menos a la iglesia con la jerarquía- corre a veces el peligro de llevar a conclusiones erróneas. Puede, por ejemplo, hacer pensar que en sus orígenes la 
iglesia era una comunidad puramente carismática, sin autoridad constituida, y que sólo más tarde fueron apareciendo los «ministerios eclesiales», según las leyes sociológicas, en función de las necesidades de la comunidad. El ministerio sería entonces un fenómeno ligado a las circunstancias, no esencial a la iglesia. Esta posición no tiene en cuenta para nada la distinción que hay entre el «ministerio eclesial» y el «Apostolado». Pero esa distinción es esencial, ya que los ministerios eclesiales brotaron efectivamente de la comunidad apostólicamente estructurada, esto es, dirigida con autoridad por los Apóstoles -por eso precisamente confesamos en el credo a la «iglesia apostólica». En virtud de esa misma Apostolicidad no podemos asegurar que los ministerios eclesiales hayan surgido en una iglesia puramente carismática, sin autoridad. Desde el comienzo, el carisma de la autoridad ha formado parte de la esencia de la iglesia. En el punto de partida del proceso sociológico de su desarrollo, en el que actúa el Espíritu de Dios, está la comunidad Apostólica"10.

Tras esta justa y teológica valoración sobre el origen del Ministerio, es preciso continuar el recorrido por el Nuevo Testamento. En sus páginas aparece la figura gigante de Pablo. Pablo es una figura sorprendente en muchos aspectos. Mas lo es principalmente en el tema del Ministerio. No fue compañero del Señor. En sus escritos apenas hay referencias a la etapa terrena de Jesús. Durante la primera andadura eclesial, después de Pentecostés, se ensañó con las seguidoras y seguidores del Señor. Mientras se dirigía a Damasco para saciar su apetito persecutorio, una voz misteriosa le llama por su nombre y le interpela por lo que está haciendo". «Saúl, Saúl, ¿por qué me persigues?». Él respondió: «¿Quién eres, Señor?». Y él. «Yo soy Jesús, a quien tú persigues»". (Hech 9,4b-5). Poco después es bautizado por un discípulo de Damasco, llamado Ananías, recobra la vista perdida y se hace propagador entusiasta del nuevo camino. (cf. Hech 9, 10-25).

Tras una breve estancia en Jerusalén, seguramente de la que él mismo habla en su carta a los Gálatas, $(1,18)$, desaparece de escena y, sin saber muy bien cuál es la razón del hecho, se vuelve a su patria, a Cilicia.

Mientras tanto ha ido tomando cuerpo e importancia la iglesia de Antioquía, capital oriental del imperio romano. A esta iglesia ha llegado un judío nacido en Chipre, llamado Bernabé. Había sido enviado por la iglesia de Jerusalén. "Cuando llegó y vio la gracia de Dios se alegró y exhortaba a todos a permanecer con corazón firme, unidos al Señor. Porque era un hombre bueno, lleno de Espíritu Santo" (Hech 11, 22-24a). 
En estos momentos Bernabé se acuerda de Saulo. Corre con premura en su busca. Y, encontrado en su tierra natal, se lo lleva a Antioquía. Aquí trabajan con entusiasmo, consiguiendo éxitos extraordinarios con su predicación. La multitud de los creyentes en Cristo aumenta vertiginosamente, siendo en esta iglesia en donde se les dio a las seguidoras y seguidores de Cristo el nombre de cristianos.

Es curioso observar que esta iglesia está dirigida por ministros de la palabra. En una de sus celebraciones litúrgicas, y seguramente por medio de uno de sus miembros, el Espíritu Santo manda separar a Bernabé y a Saulo para una misión nueva. La comunidad acepta el mensaje. Se les impone las manos como signo de comunión. (cf. Hechos 13, 1ss). Ellos, acompañados de un tal Juan, inician un viaje apostólico. Viaje que los Hechos de los Apóstoles narran profusamente.

Antes de seguir con la figura de Pablo, quiero parar mi reflexión en la iglesia de Antioquía. Tiene muchísima importancia en el tema del Ministerio. Es una buena muestra de como, al principio, la iglesia organiza su vida de formas diversas. Si la iglesia madre de Jerusalén vivió sus primeras andaduras bajo la mirada atenta de los Doce, liderados por Pedro y luego se estructuró alrededor de la figura misteriosa de Santiago, el hermano del Señor, acompañado por un gremio de ancianos, institución típicamente judía, la iglesia de Antioquía está dirigida por un grupo de profetas y maestros, ministerio más de la palabra que de dirección. Ello indica que, sobre el tema, no hay directrices concretas dadas por el Señor. Las iglesias, manteniendo eso sí su vinculación con quienes vivieron con el Señor, se organizan con libertad bajo el impuso del Espíritu Santo. Schillebeckx habla del tema con precisión teológica. Dice: "El punto central es el siguiente: la iglesia está edificada sobre los testigos inmediatos del Señor resucitado. A los ojos de muchos exegetas, la expresión «los testigos de la resurrección» (cf. Hech 1,22) -que son el fundamento de la fe y de las comunidades cristianas- es anterior a Pablo. El mismo Pablo habla de «tradición» («parádosis») de lo que él mismo ha recibido de otros (Cf. 1 Cor 15). También él remite a los testigos de Cristo resucitado, pero la lista de testigos que cita parece unir ya dos tradiciones distintas: por un lado «Pedro y los Doce», con más de quinientos hermanos» y por otra parte «Santiago y todos los apóstoles» (1 Cor 15,5-7). La expresión «Pedro y los Doce» (sin llegar aún a los Doce apóstoles) parece anterior a Pablo y, por tanto, muy antigua. Marcos habla siempre de los «Doce» o de los «doce discípulos» (sólo una vez de los «doce apóstoles»: 10,2). En la narración de la vocación de los apóstoles, utiliza una expresión fuertemente semítica: «Y él (Jesús) hizo doce» (3,13-19), lo cual revela una tradición muy antigua. 
Además, Pablo habla de las «columnas» de la iglesia de Jerusalén (Santiago, Cefas y Juan: Gál 2,9), mientras que considera su propia actividad como igualmente apostólica (1 Cor 15,8-11; 2 Cor). Según Ef 2,20, la iglesia está construida sobre el fundamento de los apóstoles y de los profetas, lo cual demuestra que la actividad carismática de ciertos miembros de la comunidad, que quizás no habían siḍo «testigos de la resurrección», formaba igualmente parte de lo que constituye, para la iglesia, su criterio y su fundamento"11.

Mirando a Pablo, prosigo el discurso iniciado por el teólogo holandés. En efecto, Pablo es un personaje del todo singular. Él se presenta siempre como apóstol de Jesucristo. Un título que otros, entre ellos Lucas, le niega casi de continuo. Sólo en contadísimas ocasiones (cf. Hech 14,14) concede a Pablo tal título. ¿A qué obedece la actitud de Lucas? Para recibir el título de apóstol, Lucas exige tres condiciones: ser testigo de la resurrección, función principal del apóstol, recibir un mandato del Señor, para llevar la buena noticia hasta el confín de la tierra, y haber acompañado al Señor desde el bautismo de Juan hasta su ascensión a los cielos. Esta última condición no la llena Pablo. De ahí que Lucas, fiel a su visión del apostolado, no concede a Pablo tal título, si no es en alguna ocasión rara en la que, con toda seguridad, está usando una fuente a la que permanece fiel. En la concepción lucana la categoría de apóstol se adecua casi en exclusiva a los Doce. Los Doce son por antonomasia los apóstoles.

Ciertamente Pablo no entra como apóstol en este horizonte de pensamiento. $\mathrm{Y}$, sin embargo, si hay algo que Pablo tiene muy claro y defiende con ardor es su condición de apóstol. Oigamos un texto apasionado: "¿No soy libre? ¿No soy yo apóstol? ¿Acaso no he visto a Jesús, Señor nuestro? ¿No sois vosotros mi obra en el Señor? Si para otros no soy apóstol, para vosotros sí que lo soy; pues ¡vosotros sois el sello de mi apostolado en el Señor!" (1 Cor 9,1-2). La carta a los Gálatas comienza con estas sorprendentes palabras: "Pablo, apóstol, no de parte de los hombres, ni por mediación de hombre alguno, sino por Jesucristo y Dios Padre que le resucitó de entre los muertos (...) $(1,1) "$.

Sorprende, y la sorpresa es de altos vuelos emotivos, que Pablo se exprese en los términos recordados. Si se aplicaran criterios simplemente humanos, nunca se podría llegar adonde Pablo llegó en su convencimiento y en sus manifestaciones. La única razón para defender su condición de apóstol de Jesucristo es "que ha recibido una aparición del Señor". Y también una misión: "éste me es un instrumento de elección que lleve mi nombre ante los

11. SchillebeEcKX, E., La misión de la iglesia, Sígueme, Salamanca, 1971, p. 482 
gentiles, los reyes y los hijos de Israel" (Hech 9,15b). Pablo está convencido de que su condición de apóstol se justifica por esa doble realidad. Y lo defiende con energía inusitada, cuando alguien se lo discute.

Nos encontramos ante un Ministerio que hay que calificar de carismático en el más profundo significado de la palabra. Cierto que todo lo que acontece en la iglesia tiene, debe tener al menos, ese carácter. Pero hay momentos en que el dato adquiere especial relevancia. Pablo no necesita ninguna justificación humana, (es el caso de los que acompañaron al Señor desde el bautismo de Juan hasta su ascensión a los cielos y algo exigido por Lucas como condición indispensable para poder ser llamado apóstol), para sentirse apóstol. Como no necesita tampoco sentirse sometido a alguien. Lo que para él es importante y necesario es conectar con la tradición jerosolimitana personificada por quienes acompañaron al Señor durante su peregrinar por la tierra.

Ilustrativo es al respecto lo que el mismo Pablo nos cuenta en la carta a los Gálatas. Tras presentarse como apóstol "no de parte de los hombres, ni por mediación de hombre alguno, sino por Jesucristo y Dios Padre" $(1,1)$, el apóstol se asombra de que los Gálatas se hayan pasado a otro evangelio. Evangelio que, según él, no existe (cf. vrs. 7-8). Y añade, por si hubiere dudas sobre la legitimidad de su evangelio: "Porque os hago saber, hermanos, que el evangelio anunciado por mí, no es cosa de hombres, pues yo no lo recibí y aprendí de hombre alguno, sino por revelación de Jesucristo" (Gál 1,11-12).

El segundo viaje a Jerusalén, narrado por Pablo en la carta a los Gálatas, presenta cosas dignas de tener en cuenta para el tema que estoy tratando. La obra de Pablo y, sobre todo, el evangelio que predicaba a los gentiles, no entraba en las mentes de muchos convertidos del judaísmo. Entre los que se encontraban personajes de gran influencia y de gran calado apostólico. Pablo no duda en llamarles "superapóstoles" (Cf. 2 Cor 11,5). Estos tales cuestionaban no sólo el título de apóstol, sino, sobre todo, el evangelio que Pablo predicaba. Factores de la vigencia de la ley mosaica, querían imponer su carga a todos los convertidos al cristianismo. La salvación conseguida por Cristo necesitaba del cumplimiento de la ley mosaica para ser efectiva.

Las cosas alcanzan un nivel tal de enfrentamiento que Pablo decide, y conforme a su testimonio por una visión del cielo, subir a Jerusalén. Es acompañado por Bernabé y Tito, convertido del paganismo. Expone su evangelio a los representantes más conspicuos, las columnas de la iglesia según Pablo. En este caso, a Santiago, que es ya el dirigente de la iglesia madre, Pedro y Juan. Después de oirlo, no sólo no le obligan a circuncidar a Tito, sino que dan la mano a Pablo y a Bernabé en señal de comunión. Es sabroso escuchar 
las palabras del mismo Pablo: "Reconociendo la gracia que me había sido concedida, Santiago, Cefas y Juan, que eran considerados como columnas, nos dieron la mano en señal de comunión a mí y a Bernabé: nosotros nos iríamos a los gentiles y ellos a los circuncisos; sólo que nosotros deberíamos tener presentes a los pobres, cosa que he procurado cumplir con todo esmero" (Gál 2,9-10).

Es el momento de recoger algunas enseñanzas de todo lo que se acaba de recordar de Pablo. La vocación de Pablo, su condición de apóstol, con todo lo que esto significa para la iglesia, que se confiesa apostólica, su actuación en libertad, el evangelio que predica, recibido de lo alto, nos están indicando algo muy importante. $Y$ todo ello avalado por el reconocimiento que la iglesia lleva a cabo tanto de la persona de Pablo como apóstol, es el apóstol por antonomasia, como del evangelio que predica. La iglesia ha incluido en el canon de libros revelados las cartas de Pablo. Pablo, por lo mismo, es el prototipo del ministro carismático en el más profundo sentido de la palabra. Con ello se acepta la libertad del Espíritu Santo, quien es el motor de la iglesia, y la posibilidad de que surja un Ministerio que rompa, por así decirlo, los cauces normales. La iglesia tiene la posibilidad de distinguir los falsos carismas de los verdaderos. Cuenta para ello con la presencia del Espíritu. Con su influjo y bajo su acción puede ejercer un verdadero discernimiento y así lograr un juicio correcto sobre la bondad de un Ministerio que no ha aparecido de forma normal. Vienen aquí muy bien las palabras de Pablo en la primera carta a los Tesalonicenses: "No extingáis el Espíritu; no despreciéis la profecía; examinadlo todo y quedaos con lo bueno" (1 Tes 5,19-22).

Schillebeeckx se refiere al tema, haciendo una valoración teológica justa. Dice: "Al introducir los escritos paulinos en el canon, la iglesia reconoció en principio, incluso para su vida actual, la posibilidad de un origen carismático del ministerio eclesial. A la luz de estos hechos históricos de la primitiva iglesia, también ahora hemos de permanecer abiertos a esa eventualidad, e incluso a su realización efectiva en las comunidades Apostólicas que se encuentran en situación crítica. Pensemos, por ejemplo, en las consagraciones ilegítimas y, por tanto, «oficialmente inválidas» de obispos, que han tenido lugar en China durante la persecución, o también en esos cristianos que se han manifestado como verdaderos jefes de la comunidad en ciertos países de misión, privados de sacerdotes durante años enteros. Sobre todo desde el punto de vista ecuménico nos parece importante esta posibilidad teológica, porque podría llevarnos a replantear la cuestión de la validez del ministerio (por ejemplo en la iglesia anglicana y en otras iglesias reformadas), ya que el carácter Apostólico de dichas iglesias es reconocido por todos y se puede 
admitir (desde el punto de vista de la iglesia romana) que se encuentran en una situación excepcional por lo que se refiere a la sucesión Apostólica en el ministerio. Al menos, dejaremos sentada su relación con el problema que acabamos de examinar: la incorporación al ministerio eclesial, o sea, en la terminología católica y según la estructuración actual de la iglesia, la ordenación episcopal, presbiteral y diaconal" 12 .

El recuerdo de Pablo y su condición de apóstol plenamente carismático, reconocido oficialmente por la iglesia, es un buen dato y una buena noticia para las aspiraciones del movimiento ecuménico. Movimiento que, como sabemos, está empeñado en alcanzar, bajo el impulso del Espíritu Santo, la unión de las iglesias de Cristo. Y en cuyo camino el tema del Ministerio es un obstáculo grande. Y lo es por muchos motivos. Uno de los cuales se halla en la aplicación estricta de la forma de acceder al mismo. La forma tradicional más común ha sido, y sigue siendo, la que tiene por protagonista la figura del obispo. Y además el obispo que se halla inmerso en una sucesión apostólica que, a través de los tiempos, le conecta con los apóstoles. Si falta, por tanto, la figura de obispo o si ha sido rota la sucesión apostólica por algún defecto de forma o de intención, entonces se abre una brecha de tal naturaleza que el acceso al Ministerio resulta inviable.

Algo de esto refleja el concilio Vaticano II en el siguiente texto: "Las comunidades eclesiales separadas, aunque les falta esa unidad plena con nosotros que dimana del bautismo, y aunque creamos que, sobre todo por la carencia del sacramento del Orden, no han conservado la genuina e íntegra sustancia del misterio eucarístico, sin embargo, mientras conmemoran en la Santa Cena la muerte y la resurrección del Señor, profesan que en la comunión de Cristo se significa la vida, y esperan su glorioso advenimiento. Por consiguiente, la doctrina sobre la Cena del Señor, sobre los demás sacramentos, sobre el culto y los ministerios de la iglesia debe ser objeto de diálogo"13.

No hace falta mucha perspicacia para detectar que la expresión conciliar "sobre todo por la carencia del sacramento del Orden" se refiere inequívocamente a la ausencia del Ministerio episcopal. Queda así comprometida la permanencia en el auténtico Ministerio y, por lo mismo, la validez de la celebración eucarística. Son hechos reales. No se puede marginar su importancia. Cierto que el mismo concilio Vaticano II no cierra la puerta de un diálogo fructífero para alcanzar nuevas metas y encontrar datos que aclaren el tema. Aquí es donde puede ofrecer un perfil novedoso la figura ministerial de

12. SCHILlEBEECKX, E., La misión de la iglesia, Sígueme, Salamanca, 1971, pp. 497-498 13. UR. 22c. 
Pablo. Pablo no entra en el engranaje del Ministerio apostólico por la línea normal. Su Ministerio es estrictamente carismático, sin que esta palabra signifique que los otros Ministerios no sean también carismáticos. Si Pablo fue reconocido por la iglesia como apóstol, y no sólo como apóstol, sino también como apóstol de los apóstoles, fue, sin duda, debido a la bondad de sus trabajos. Se cumple aquí aquello de que "por sus frutos los conoceréis" (Mt 7,20).

El reconocimiento de Pablo como apóstol abre a la posibilidad de encontrarse con Ministerios de carácter eminentemente carismático. Es decir, Ministerios que se apartan del cauce normal. Ministerios cuyo valor y fuerza se halla en la actuación misteriosa y sorprendente del Espíritu Santo y los frutos de verdad obtenidos.

Uno se sorprende gratamente al escuchar la forma en que se habla hoy sobre el Ministerio de comunidades que hasta hace muy poco se consideraba en nuestro entorno como inválido. Todos recordamos la declaración solemne de León XIII que proclamaba la invalidez de las ordenaciones anglicanas. "Así, pues, asintiendo de todo punto a todos los decretos de los Pontífices predecesores nuestros sobre esta misma materia, confirmándolos plenísimamente y como renovándolos por nuestra autoridad, por propia iniciativa y a ciencia cierta, pronunciamos y declaramos que las ordenaciones hechas en rito anglicano han sido y son absolutamente inválidas y totalmente nulas"14. Todos somos conscientes de cómo se consideraban los caminos de acceso al Ministerio en las comunidades salidas de la Reforma. Eran comunidades que no estaban en la sucesión apostólica y, por lo mismo, sus ritos de acceso al Ministerio eran absolutamente nulos.

Hoy nadie se atreve a hacer afirmaciones tan rotundas. Al contrario, teólogos de mucha altura, grupos de trabajo ecuménico de diverso signo no tienen reparo en afirmar que esas iglesias se hallan en posesión de un Ministerio válido. Los miembros luteranos del Grupo Luterano-Católico de Estados Unidos hacen esta declaración sorprendente: "Los luteranos abordan las cuestiones tratadas en esta declaración conjunta apoyándose en la convicción de que sus iglesias pertenecen a la iglesia una, santa, católica y apostólica. Ellos consideran sus ministros ordenados como personas válidamente segregadas para el Ministerio del evangelio y de los sacramentos en la iglesia de Cristo. Afirman que los sacramentos administrados entre ellos por estos

14. Denzinger, E., El magisterio de la iglesia, Herder, Barcelona, 1965, nr.1966, p. 465. 
ministros ordenados son sacramentos válidos. Los luteranos sostienen que en sus escritos confesionales permanecen en la auténtica tradición católica"15.

Los teólogos católicos de este grupo hacen del tema la siguiente valoración: “A primera vista resultaría fácil determinar la postura católico-romana en torno al Ministerio eucarístico luterano. Una expresión simplista del punto de vista tradicional católico-romano diría que quienes presiden la eucaristía lo hacen en virtud de la ordenación recibida de un obispo que está en sucesión con los apóstoles, que a su vez recibieron de Cristo el mandato «haced esto en memoria de Mí».

Cuando falta esta ordenación nadie puede atribuirse un Ministerio eucarístico válido. Ahora bien, en el tiempo de la Reforma en Alemania los obispos no ordenaron Ministros para las congregaciones que declararon seguir a Martín Lutero; y así sucedió que los sacerdotes que se habían hecho luteranos ordenaron a otros para presidir la eucaristía, perpetuando de esta forma una sucesión presbiteral más bien que una episcopal. Para la mayoría de los luteranos no hay lugar a exigir un episcopado en sucesión histórica de los apóstoles. De esta forma el Ministerio eucarístico luterano parece ser deficiente en aquellos elementos que hasta el presente han sido considerados por los católicos como esenciales.

Sin embargo, al estudiar nosotros católicos en este diálogo el problema, nuestras objeciones tradicionales hacia un Ministerio eucarístico luterano parecen haber perdido fuerza y existen razones para una consideración positiva"16.

A continuación los teólogos católicos emprenden la tarea de apoyar su declaración en argumentos históricos y teológicos. Y a fe que las razones que ofrecen son dignas de tenerse en cuenta y abren horizontes amplios para una valoración positiva del Ministerio eucarístico luterano.

La comisión internacional anglicano-católica romana afirma: "Somos plenamente conscientes de las cuestiones suscitadas por el juicio de la iglesia católica romana sobre las ordenaciones anglicanas. El desarrollo del pensamiento de nuestras comunidades referentes a la naturaleza de la iglesia y del ministerio ordenado, como se manifiesta en nuestra Declaración, consideramos que coloca esas cuestiones en un nuevo contexto. Un acuerdo sobre la naturaleza del ministerio es previo a la consideración del mutuo reconocimiento de ministerios. Lo que nosotros tenemos que decir representa el con-

15. Grupo Teológico Luterano-Católico de Estados Unidos. Eucaristía y Ministerio, Seminarios 57-58, Sígueme, Salamanca, 1975, nr. 23, p. 476.

16. Grupo Teológico Luterano-Católico de Estados Unidos. Eucaristía y Ministerio, nrs. 36 y 37. Seminarios 57-58, Sígueme, Salamanca, 1975, pp.480-481. 
senso de la Comisión sobre materias esenciales en las que se considera que la doctrina no admite divergencias. Está claro que no hemos citado aún el extenso problema de la autoridad que surgirá en alguna discusión sobre el ministerio, ni la cuestión de la primacía. Nos damos perfecta cuenta de que el presente entendimiento de algunas materias sigue siendo un obstáculo para la reconciliación de nuestras iglesias en la comunión que deseamos, y la Comisión está volviendo ahora al examen de las cuestiones implicadas. No obstante, consideramos que nuestro consenso sobre cuestiones en las que es indispensable un acuerdo para la unidad, ofrece una contribución positiva para la reconciliación de nuestras iglesias y de nuestros ministerios"17.

Si se compara el texto de la Comisión internacional anglicano-católica romana con la declaración de León XIII sobre la validez de las ordenaciones anglicanas, se nota, sin excesivo esfuerzo mental, una diferencia muy grande. El papa declara tales órdenes inválidas. Lo hace en base a un defecto de forma. La comisión, que no hace un juicio valorativo definitivo sobre el tema, se expresa así: "El desarrollo del pensamiento de nuestras Comunidades referentes a la naturaleza de la iglesia y del ministerio ordenado, como se manifiesta en nuestra Declaración, consideramos que coloca esas cuestiones en un nuevo contexto". Es claro que, sin decirlo, la Declaración tiene ante sus ojos todo lo que una investigación serena y técnica ha aportado acerca del desarrollo del Ministerio en el Nuevo Testamento. En concreto, lo que la Escritura nos dice acerca de la persona de Pablo.

Dejando a la persona de Pablo, paso ahora a tratar de la organización de las iglesias. Me fijo de manera especial en las iglesias vinculadas directa o indirectamente con Pablo. Ya algo se ha dicho sobre la iglesia de Jerusalén que, tras los primeros pasos dados de la mano de los Doce, los compañeros de la vida terrena de Jesús, capitaneados por Pedro, pasa a ser dirigida por Santiago, el hermano del Señor, y un grupo de ancianos, institución ésta muy habitual en la cultura judía. Antioquía, muy pronto el centro misionero más importante de la primitiva iglesia, tiene unos dirigentes de elevado carácter verbal. Son profetas y maestros, ministerios de la palabra más que de gobierno (Cf. Hech 13,1ss).

Seguramente que la iglesia que más puede servir en la tarea emprendida es la iglesia de Corinto. Fue la iglesia que Pablo tuvo siempre en las niñas de sus ojos. Por ello, es la iglesia que mejor se conoce. Antes de desarrollar el tema, se impone constatar algunas cosas. Por más que se hable de que

17. Comisión Internacional Anglicano-Católica Romana. Ministerio y ordenación, Seminarios 57-58, Salamanca, 1975, nr. 17, p. 532. 
Corinto tiene una organización eminentemente carismática, es decir, que la organización apenas si deja descubrir su presencia, no se puede olvidar que nunca se dieron iglesias á-cratas. En ellas se dio siempre la misión de dirigentes. Valgan de confirmación a lo dicho algunos párrafos de Margaret Y. Macdonald en su libro: Las comunidades paulinas. "Es imposible estudiar el liderazgo de las comunidades paulinas sin considerar cómo se relaciona Pablo con ellas. Uno de los rasgos más llamativos de esta relación es la libertad de interpretación y la flexibilidad para tomar decisiones que Pablo da a sus destinatarios. $\mathrm{H}$. von Compenhausen considera muy importante este fenómeno. Señala la fuerte reacción de Pablo, cuando alguien piensa que la autoridad pertenece sólo a ciertos individuos de la comunidad (1 Cor 3,5). Las comunidades no deben estar sujetas a los apóstoles o maestros, sino sólo a Cristo. Pablo no fue crucificado por los corintios, y los corintios no fueron bautizados en nombre de Pablo (1 Cor 1,13). Pablo planta, Apolo riega, pero es Dios quien hace crecer (1 Cor 3,5-9). La libertad de la comunidad está insinuada en la exigencia de Pablo en 1 Cor 11, 1: «Sed imitadores míos como yo lo soy de Cristo». Pablo no da órdenes. Se preocupa, incluso, de si la colecta podría resultar gravosa a los miembros de sus comunidades (2 Cor 8,8-15; 1 Cor 7,35)"'18.

"Con el paso del tiempo y el crecimiento del grupo, se produce la diferenciación estructural. Con la multiplicación de ámbitos sociales surge el problema de mantener una cobertura estable para todo el grupo. La pluralidad y el conflicto exigen la continua legitimación del universo simbólico. Por el mismo texto tenemos la impresión de que existía una red compleja y fluida de líderes que cohesionaban las comunidades. Silvano, Sóstenes y Timoteo son nombrados, por lo menos una vez, como coautores con Pablo de una carta (1 Cor 1,1; 2 Cor 1,1; Flp 1,1; 1 Tes 1,1). Pablo envió a Timoteo a apoyar a los tesalonicenses (1 Tes 3,2). Timoteo y Silvano ayudaron a fundar la secta paulina en Corinto ( 2 Cor 1,19). Tito estuvo implicado, de algún modo, en las relaciones entre Pablo y los corintios, incluyendo los preparativos para la colecta (2 Cor 2,13; 7,6-15; 8,6.16-24). Apolo trabajó, es verdad, independientemente de Pablo, pero estaba, sin embargo, íntimamente relacionado con él como «colaborador» y hermano con una tarea diferente dentro de la obra de Dios (1 Cor 3,5-8; 4,6; 16,12). Bernabé compartió la misión de Pablo a los gentiles. Los acontecimientos que se describen en Gál 2 demuestran la 
independencia de Bernabé, pero Gál 2 y 1 Cor 9 indican que Pablo entendió que ambos estaban relacionados con los líderes de Jerusalén (1 Cor 9,6)"19.

Dos cosas quedan retratadas en los textos citados. Una de ellas nos habla del liderazgo ejercido por Pablo en sus comunidades, en general, y en la comunidad de Corinto, en particular. Otra, de la evolución que con el tiempo se va produciendo en lo que respecta a la estructuración de las comunidades. Es normal, y ello aconteció en los primeros años de la iglesia, que la comunidad se desentienda un tanto de la organización. Son otros los intereses que tiene entre manos. En este preciso momento interesa más matizar y predicar el mensaje que la organización. Al paso del tiempo, y teniendo en cuenta que el fundador desapareció ya o está para desaparecer, se impone consolidar el mensaje. Y, para ello, la organización impone su ley.

Prosiguiendo en la comunidad de Corinto y sin olvidar que estamos en su primera andadura, andadura que se hace bajo la mirada atenta de Pablo, es preciso poner de relieve algunas cosas de abierta incidencia en el tema del Ministerio. Pablo concede un gran papel a la comunidad como tal. Es costumbre paulina comenzar sus cartas dirigiéndose a la comunidad. Escuchemos su saludo a la comunidad de Corinto. "Pablo, llamado a ser apóstol de Cristo Jesús por la voluntad de Dios, y Sóstenes, el hermano, a la iglesia de Dios, que está en Corinto: a los santificados en Cristo Jesús, llamados a ser santos, con cuantos en cualquier lugar invocan el nombre de Jesucristo, Señor nuestro, de nosotros y de ellos, gracia a vosotros y paz de parte de Dios, Padre nuestro, y del Señor Jesucristo" (1 Cor 1,1-3). La característica apuntada se mantiene incluso en aquellas iglesias en las que consta que hay episcopoi y diaconoi. Tal sucede con la iglesia de Filipos. "Pablo y Timoteo, siervos de Cristo Jesús, a todos los santos, que están en Filipos, con los episcopos y diáconos. Gracia a vosotros y paz de parte de Dios nuestro Padre y del Señor Jesucristo" (1,1-2).

Fiel a esta consigna, Pablo quiere que la comunidad se responsabilice de los problemas que tiene en su seno. La primera carta a los Corintios es un claro ejemplo del tema. Todos los conflictos, que padece, deben ser resueltos de forma comunitaria. Recordemos al respecto un caso bien significado. Se trata de juzgar a un miembro de la comunidad que está conviviendo con su madrastra. Pablo les invita a tratar el caso en comunidad y a tomar una decisión que haga salir de su letargo al hombre en cuestión y así conseguir que rectifique su conducta. "En el nombre del Señor Jesús, reunidos vosotros y mi espíritu, con el poder de Jesús Señor nuestro, sea entregado ese individuo

19. Ib. p.89. 
a Satanás para destrucción de la carne, a fin de que el espíritu se salve en el Día del Señor" (1 Cor 5, 4-5).

El caso más emblemático en el tema es, sin lugar a dudas, la celebración eucarística. Se trata, como se puede ver con facilidad, de una realidad que debe informar la vida del creyente. Pablo habla de la institución de la eucaristía con un lenguaje técnico. Lo que él sabe del tema lo ha recibido por tradición. Tradición recibida del Señor, que él, a su vez, transmite a los corintios. El verbo griego paralambano, usado aquí por Pablo, significa recibir un mensaje de alguien, para luego transmitirlo a otros. Así las cosas, Pablo relata la institución de la eucaristía en los términos siguientes: "Porque yo recibí del Señor lo que os he transmitido: que el Señor Jesús, la noche en que fue entregado tomó pan, y, después de dar gracias, lo partió y dijo. « Éste es mi cuerpo que se da por vosotros; haced esto en recuerdo mío». Asimismo también el cáliz despues de cenar diciendo: «Este cáliz es la Nueva Alianza en mi sangre. Cuantas veces lo bebiereis, hacedlo en recuerdo mío" (1 Cor 11,23-25).

Pablo no sólo transmite lo que ha recibido acerca de la eucaristía, sino que también elabora una hermosa teología del sacramento de la eucaristía. El texto programático es éste: "Porque, aun siendo muchos, un solo pan y un solo cuerpo somos, pues todos participamos de un solo pan" (1 Cor 10,17). Pablo descubre una identidad total entre el cuerpo eucarístico y el cuerpo comunitario. Ambos son el cuerpo de Cristo. Quien desconoce el cuerpo de Cristo, que es el hermano, se incapacita para conocer el cuerpo de Cristo eucarístico.

Tal es el caso de Corinto. Los corintios se reúnen para celebrar la eucaristía. Pero dicha celebración está corrompida en su más profundo significado. Falta la unión entre los miembros que la celebran. Hay división. Se descuida la caridad. Mientras unos están hartos, otros padecen necesidad. Pablo les hace ver que una tal eucaristía no sirve para nada.

Lo que se debe resaltar en todo este grave asunto es que Pablo hace responsable a toda la comunidad. "Así, pues, hermanos míos, cuando os reunís para celebrar la Cena, esperaros los unos a los otros. Si alguno tiene hambre, que coma en su casa, a fin de que no os reunáis para castigo vuestro" ( 1 Cor 11,33-34). No dice: «que los responsables o dirigentes de la comunidad solucionen el problema; impongan su criterio». No. Es la comunidad la que debe tomar cartas en el asunto y ver qué formas de actuación debe poner en marcha.

Annie Jaubert retrata muy bien la relación que existe entre Pablo y las comunidades por él fundadas. "Esas comunidades fueron con frecuencia lugares de vivas tensiones. Tensiones que no se resuelven «extinguiendo el 
Espíritu», es decir, ignorando los dones espirituales, ni siquiera los difíciles de catalogar. Pablo admira la libertad del Espíritu. Él mismo recibió una llamada carismática (el elemento imprevisible que atraviesa las estructuras). Todos los dónes y todos los oficios deben ser orientados a construir el cuerpo de Cristo por la sumisión al mismo evangelio. Todos, con una obediencia de fe, deben cooperar a la obra única y multiforme de Dios. Pablo procura resolver las tensiones o hacer desaparecer los abusos -salvo algunos casos graveshaciendo una llamada a la comunión, a las responsabilidades de todos; a un diálogo, en una palabra. Los contactos con la autoridad no son de tipo jurídico; se encuadran en una relación de caridad y de cooperación mutuas"20.

Resaltado el papel que Pablo concede a la comunidad, es preciso ver ahora el modo cómo se organizan las comunidades paulinas. La sorpresa nos va a salir al paso. Las comunidades paulinas tienen dirigentes. Es un hecho real. Pero este Ministerio no tiene una configuración definida. Es preciso adelantar que Pablo concede a este Ministerio un papel bastante secundario. Cuando habla de las diversas actividades en la comunidad, actividades que tienen sus protagonistas y, sobre toto, su fuente última que es el Espíritu Santo, Pablo da un lugar de privilegio a los Ministerios de la palabra. Oigámosle: "Ahora bien, vosotros sois el cuerpo de Cristo, y sus miembros cada uno por su parte. $\mathrm{Y}$ así los puso Dios en la iglesia, primeramente apóstoles; luego, profetas; en tercer lugar, como maestros; luego, el poder de los milagros; luego, el don de las curaciones, de asistencia, de gobierno, diversidad de lenguas" (1 Cor 12,27-28).

Es importante parar mientes en el párrafo citado. Aparece con claridad meridiana que Pablo valora por encima de todo los Ministerios de la palabra: apóstoles, profetas, maestros. No debe extrañar en absoluto tal postura. Hay que tener en cuenta que la iglesia de entonces se halla en un periódo de creación y de formación y de expansión. Aunque los tres Ministerios son Ministerios de la palabra, su servicio a la misma no es uniforme. ¿Qué función desempeñan cada uno de los miembros de la triada? "Los apóstoles, a quienes hay que distinguir del grupo de los Doce, son ante todo unos misioneros enviados oficialmente por su comunidad. Su campo de acción se delimitó cuando fueron enviados a misionar; de ahí la importancia que tiene la noción de «medida» (2 Cor 10,13). En general viajan de dos en dos provistos de cartas de recomendación, y las comunidades cristianas que visitan deben recibirlos «como al Señor» (Didaché XI, 4; cf. Gál 4,14). Dar a los apóstoles

20. Las epístolas de Pablo. El hecho comunitario, en el ministerio y los ministerios según el Nuevo Testamento, Ed. Cristiandad, Madrid, 1975, p. 38. 
el primer lugar en esta tríada indica claramente la orientación misionera de la iglesia, especialmente la de Antioquía, en esta época.

Los profetas desempeñan un papel de primera línea en las asambleas cristianas: «El que profetiza edifica a la iglesia» (1 Cor 14,4 ; cf. v. 22). «El que hace oficio de profeta habla con los hombres para edificarlos, exhortarlos y consolarlos» (1 Cor 14,3). Por tanto, aparte de otras funciones, los profetas se encargan de la homilía y la predicación en las asambleas litúrgicas. Más aún: la Didaché, confirmando las alusiones de 1 Cor 14,15-17, recomienda que «les dejen dar gracias (eucharistein) todo el tiempo que quieran». Por tanto recitan también plegarias de bendición o «eucarísticas». Según Hech 4,36; 13,1.15-23, los profetas son líderes de importantes comunidades locales (Antioquía, Jerusalén) y de entre ellos son escogidos los apóstoles. Este papel importantísimo de los profetas en la comunidad cristiana explica la insistencia de Pablo en el don de profecía: «No despreciéis las profecías» (1 Tes 5,20; cf. Rom 12,6). «Codiciad los dones espirituales, sobre todo el de profecía» $(1$ Cor 14,1).

A los doctores (didaskaloi) los conocemos sólo por algunas alusiones: en general van asociados con los profetas, juntos en la tríada precedente, pero también fuera de esa enumeración (Hech 13,1, Didaché XII, XV). Se encargaban de la didaskalia, enseñanza bastante metódica que se apoyaba en las Escrituras, probablemente como lo hacían los rabinos judíos, es decir, siguiendo una tradición de escuela. Quizá Pablo y Apolo, que habían tenido una formación rabínica (Hech 18,$24 ; 22,3$ ), fueron reconocidos como «doctores» (cf. Hech 11,26; 13,1 para Pablo), antes de ser enviados oficialmente por sus comunidades como «apóstoles»"21.

La cita paulina coloca en un lugar muy discreto el carisma de gobierno. Es el penúltimo de la lista. Y, desde luego, no es calificado con un título particular. En este aspecto concreto, y sabiendo que las comunidades paulinas tienen dirigentes, hay que reconocer que la nominación es muy variada y genérica, si se exceptúa la carta a los Filipenses, única carta paulina que habla de episcopoi y diaconoi. (cf. 1,1). El primer escrito paulino, la carta primera a los Tesalonicenses, habla de los que trabajan entre vosotros (kopiontas), os presiden (proistamenous) y os amonestan (nouzetountas). Para ellos pide estima a causa de la obra que están haciendo.

Cerca ya del final del capítulo 16 de la primera carta a los Corintios, Pablo hace referencia a la familia de Estéfanas. Es la primicia de Acaya. Y lo

21. Lemaire A., Las epístolas de Pablo. Diversidad de los ministerios, En El ministerio y los ministerios según el Nuevo Testamento, Cristiandad, Madrid, 1975, pp. 63-64. 
más importante es que se ha puesto al servicio de los santos. Es importante fijarse en el texto griego para alcanzar el sentido profundo del mismo. Se dice: "eís diakonían toís ayíois etaxan eautoús" (1 Cor 16,15). Es preciso resaltar la espontaneidad del acontecimiento. Se han ofrecido a sí mismos para una misión de servicio. En el fondo, para una misión de dirección. Es verosímil que todo ello tuviera alguna forma oficial, a la hora de llegar a tal situación. La comunidad, al menos, daría su veredicto. Y seguramente Pablo tuvo que ver en el tema de una forma o de otra. Mas ello no empaña el dato apuntado, que, de alguna manera, deja al descubierto que todavía no hay fórmulas propiamente rituales para acceder a un Ministerio.

Rico también es el contenido del último capítulo de la carta a los Romanos. Al principio del mismo, Pablo recomienda a Febe, diaconisa de la iglesia de Cencreas. "Recibidla en el Señor de una manera digna de los santos, y asistidla en cualquier cosa que necesite de vosotros, pues ella ha sido protectora (prostatis) de muchos, incluso de mí mismo" (Rom 16, 1-2).

Lo recordado nos obliga a sacar algunas conclusiones decisivas para el tema propuesto. Las iglesias paulinas tienen una organización diversa. Y ello es un dato clarísimo de que Jesús no dio un modelo concreto de organización, como tampoco creó figuras concretas del Ministerio. Si esto hubiera existido, Pablo, que era enormemente sensible a mantenerse unido a la tradición de Jerusalén, no se hubiera apartado de la consigna de Jesús.

Por lo mismo, las figuras ministeriales que, a partir del siglo II bien entrado, quedaron en la iglesia, llámense obispos, presbíteros y diáconos, son consecuencia de una evolución, que cuenta con una actuación del Espíritu, pero que también es deudora de un entorno cultural determinado. La evolución es legítima y se hace bajo la acción del Espíritu. Asi lo recordaba Schillebeeckx en el texto anteriormente citado. Pero no tiene carácter absoluto. Puedo haberse realizado de otra forma. Y, por ello, deja amplio margen para aceptar cambios que con el tiempo se puedan ver como necesarios para que la iglesia cumpla la misión encomendada.

Es el momento de tomar el pulso al tema aludido de la evolución reflejada en el Nuevo Testamento. Me sitúo a finales del siglo I, tiempo en que aparecen unas cartas atribuidas durante mucho tiempo a Pablo, pero que la investigación moderna les niega tal paternidad. Se trata de las llamadas cartas pastorales.

Las cartas pastorales reflejan una serie de datos que hablan de cambios acaecidos de alto nivel significativo. Las comunidades cristianas llevan ya sobre sus espaldas un tramo de tiempo bastante grande. Han desaparecido ya los testigos oculares y ministros de la palabra, sobre quienes recayó la res- 
ponsabilidad de llevar el mensaje. Un mensaje que en su primera andadura revestía una característica muy peculiar. Era, ante todo y sobre todo, mensaje vivo. Dicho en términos técnicos era paradosis. La paradosis es, por encima de todo, transmisión viva y enriquecida del mensaje. Impone el tono de entrega. Se entrega vivencialmente lo que se ha recibido. $Y$, con ello, se construye la comunidad. Es, como se ve, una etapa novedosa y creadora.

En el tiempo de las cartas pastorales el clima es distinto. No se trata de crear y, aunque no se excluye, tampoco se trata en primera línea de transmitir. Se trata de conservar lo recibido en la pureza total y pasarlo a las generaciones venideras, como si se tratara de una perla preciosa.. La primera preocupación de las comunidades de las pastorales es la fidelidad al mensaje recibido. La paradosis se ha convertido en paratheke. La paratheke es un depósito que hay que guardar con esmero, para poderlo entregar sin tocarlo. Es una especie de cofre cerrado que se guarda con mimo. Hay un grito que se repite en las cartas pastorales. Es éste: "Timoteo, guarda el depósito (=paratheke) (1 Tim 6,27a) "Conserva el buen depósito mediante el Espíritu Santo que habita en nosotros (2 Tim 1,14)". "Vela por ti mismo y por la enseñanza; persevera en esta disposición, pues obrando así te salvarás a ti mismo y a los que te escuchen" (1 Tim 4,16)". "Tú, en cambio, persevera en lo que aprendiste y en lo que creíste, teniendo presente de quiénes lo aprendiste (2 Tim $3,14) "$

Es, como se puede detectar fácilmente, una consigna dominada por el ansia de ser fieles a lo recibido. Consigna que se encuentra reforzada por estas palabras: “Tú, hijo mío, manténte fuerte en la gracia de Cristo Jesús ; y cuanto me has oído en presencia de muchos testigos confíalo a hombres fieles, que sean capaces, a su vez, de instruir a otros (2 Tim 2,1-2)".

Las cartas pastorales están dominadas por esa inquietud. Pablo, ya no es tanto el apóstol, como el gran didascalos. Es el maestro cuyas enseñanzas constituyen el tesoro de la paratheke. Conservarlo es la tarea primordial que se descubre en las cartas pastorales.

El dato, cuyas consecuencias ministeriales se reflejarán más tarde, viene reforzado por la tardanza de la parusía, la segunda venida del Señor. Nos encontramos a finales del siglo I, año arriba, año abajo. Han desaparecido los primeros testigos. La segunda venida del Señor, considerada inminente, no se realiza. La iglesia o las iglesias toman conciencia de que hay que prepararse para una larga estancia en la tierra. Y ello lleva sus repercusiones en la estructura. Las cosas no están ya para aventuras. Ni tampoco, para dejarlo todo a la improvisación. El Espíritu Santo ya no actúa en la forma en que lo hacía en los primeros años. Quiero decir que la actuación del Espíritu no aparece 
tan sensible como en tiempos anteriores. Cuesta más descubrirla y está sometida a posibles interpretaciones equivocadas. Por eso, impone su ley lo institucional. El Ministerio de dirección apunta ya a un horizonte muy concreto. Se va ya, si es que no se ha llegado aún, hacia el obispo monárquico, del que habla ya claramente Ignacio de Antioquía. El obispo, en germen o ya en acto, será o es el hombre de la palabra, el presidente del culto y el jefe de la comunidad. El que tuvo sólo una función de vigilancia, viene a constituirse en una figura poseedora de la triple función antes recordada.

Lo institucional, por decirlo de alguna manera un tanto cruda, planta sus reales en las iglesias. Y, aunque hay que ser muy cautos a la hora de valorar el hecho, para no caer en el equívoco de oponer la institución al carisma, la institución es también carisma, sin embargo no se puede marginar que, en base a su propio dinamismo, la institución corre el grave peligro de encerrarse en sí misma, de instalarse y de hacerse valer por sí misma, perdiendo así el dinamismo de lo propiamente carismático. Es lo que Max Weber ha designado con la frase la "rutinización del carisma". "De este modo, la rutinización del carisma toma la forma de apropiación de poderes, de control y de ventajas económicas por el equipo dirigente, de modo que sólo ellos pueden ejercer la autoridad. Además el equipo dirigente puede establecer formas de reclutamiento que incluyen, con frecuencia, preparación y pruebas de admisión. Señala Weber que, para que el carisma se transforme en una estructura permanente, es esencial que se altere su carácter anti-económico. Hay que afrontar las necesidades económicas de la comunidad. Hay que arbitrar medios para allegar recursos.

Weber insiste, sin embargo, en que, incluso cuando el carisma se ha rutinizado y no puede ser ya entendido como personal y anti-económico, está justificado hablar de carisma, porque permanece una cualidad extraordinaria, no accesible a todos, planeando sobre los sujetos carismáticos. Tras su rutinización, el carisma puede servir de medio importante de legitimación de la autoridad de los sucesores del héroe carismático. Por ejemplo el carisma puede rutinizarse en carisma de oficio. El carisma se disocia de un individuo particular y se convierte en una realidad objetiva transferible. Puede ser transmitido de un individuo a otro, por ejemplo, a través de la imposición de manos. Aún cuando el carisma se convierta en estructura permanente y su esencia y modo de obrar se transformen significativamente, persiste, sin embargo, como un elemento muy importante de la estructura social"'22.

22. MACDONALD, M. Y., Las comunidades paulinas, Sígueme, Salamanca, 1994, pp.32-33. 
"En Asia Menor es donde mejor podemos seguir la génesis del ministerio episcopal. Las cartas de san Ignacio de Antioquía (Párrafo 12) ya contienen el dicho: «Quien se opone a él (al obispo) se opone a Dios»; «donde está el obispo está la comunidad, lo mismo que donde está Cristo está la iglesia católica». Por esta carta y por las de san Policarpo sabemos que hacia finales del siglo ya se habían separado los ministerios del obispo y del sacerdote; el primer nombre se reservó para el jefe de la comunidad: el obispo. Los presbíteros se convirtieron en sus auxiliares (...).

El obispo era el que convocaba a todos los clérigos y les confería el ministerio. Toda la vida de la comunidad (bautismo, penitencia, servicio divino, exclusión e incorporación, es decir, enseñanza, orden de la comunidad y vida litúrgico-sacramental) estaba bajo su dirección (= «cura de almas»)"23.

Es el momento de hacer un balance crítico del pequeño, pero suficiente, recorrido que se ha hecho por el Nuevo Testamento, para detectar el modo y la forma como comenzó y se desarrolló ministerialmente la iglesia. La iglesia, nacida de y apoyada en el ministerio apostólico, cumple la misión recibida del Señor bajo la acción de su Espíritu de forma creativa y plural. El Ministerio clave es el Ministerio apostólico. Ministerio no reducible simplemente a los Doce, el grupo que vivió y recibió las enseñanzas inmediatas de Jesús. Pablo, seguramente el apóstol que más trabajó por llevar el evangelio a todo el mundo conocido, no perteneció a este grupo.

La persona de Pablo, ya se dijo, es revulsiva de formas reduccionistas a la hora de hablar del Ministerio y de su acceso. Pablo es el Ministro carismático por antonomasia. Digo "por antonomasia", para dar a entender que también los otros Ministerios, en concreto el de los Doce, gozan de la misma dignidad, aunque estos últimos cuentan con la garantía histórica de ser los compañeros y confidentes de Jesús . Siempre se presenta como apóstol. Misión recibida de lo alto. Su evangelio es también de origen divino. El reconocimiento que la iglesia ha hecho tanto de su persona como apóstol, como de sus escritos, es un signo inequívoco de que el Espíritu no está sujeto en su actuación a esquemas prefabricados. Puede, y de hecho lo hizo con Pablo, marcar otros caminos. Y así queda la puerta abierta para que lo que sucedió una vez y con una persona concreta, suceda en otras ocasiones y con otras personas.

También ha quedado suficientemente probado que el Nuevo Testamento se hace eco de muy diversas formas de Ministerio. Las iglesias, eso sí dirigidas por el Espíritu, se organizan ministerialmente de formas diversas. En el hecho influye de forma muy viva la situación cultural en que nace una iglesia

23. LoRzT. J., Historia de la iglesia I. De. Cristiandad, Madrid, 1982, pp. 124-125. 
concreta. Basta para ello recordar a la iglesia de Jerusalén, a la iglesia de Antioquía, a la iglesia de Corinto, a la iglesia de Filipos. Hay, por lo mismo, una variedad rica de Ministerios. Incluso la iglesia se permite, ante una necesidad concreta, crear un Ministerio para atender dicha necesidad (Cf. Hech 6).

Hay una etapa en la que la denominación es todavía no suficiente matizada. Es la época en la que se habla de los presbiteroi-episcopoi. Es clásico al respecto el famoso capítulo 20 de los Hechos de los Apóstoles. Pablo se dirige a Jerusalén. Al llegar a Mileto, convoca a los presbísteros de Éfeso. Con ellos tiene un encuentro cargado de emoción. Les anuncia tiempos difíciles, en los que aparecerán lobos rapaces que no tendrán compasión de la iglesia que el Señor compró con su sangre. Y les recomienda encarecidamente: "Tened cuidado de vosotros y de toda la grey, en medio de la cual os ha puesto el Espíritu Santo como vigilantes (épiscópous), para pastorear (poimanein) la iglesia de Dios, que él se adquirió con su propia sangre" $(20,28)$. Es preciso fijarse y resaltar que quienes al principio del relato son llamados presbíteros ahora se les da el nombre de epíscopos. El lenguaje, como se ve, no está aún suficientemente determinado y, por lo mismo, se aplica indistintamente a las mismas personas.

Este capítulo es para mí uno de los más significativos a la hora de hablar de la evolución del Ministerio en el Nuevo Testamento. Es preciso fijarse en la expresión: para mí. Viene a ser como un espacio intermedio entre lo que acontece en las iglesias paulinas durante la vida de Pablo y lo que acontecerá en las iglesias a las que se dirigen las cartas pastorales. La situación eclesial en el caso está cambiando. Aparecen los peligros. Es preciso tomar medidas. Y, como sucede en casos como éstos, los Ministerios de dirección se van reforzando. Lo que Pablo, según el texto, pide a los dirigentes de Éfeso oteando un poco el horizonte, eso es lo que tiene plena vigencia en las iglesias de las pastorales.

El complejo mundo del Ministerio, su evolución hasta alcanzar las formas que hoy conocemos, invitan y exigen cuidar con mimo tanto los contenidos, como el lenguaje del mismo. Se da con mucha frecuencia la tendencia a acudir a voluntades de Cristo, cuando se trata de justificar la presencia de un Ministerio concreto. Por ejemplo: si es voluntad de Cristo que su iglesia tenga obispos, no se ve la posibilidad de salvar la eclesialidad de aquellas comunidades que han prescindido de tal figura. Si la sucesión episcopal es requisito indispensable para que una iglesia esté en la sucesión apostólica, tampoco se alcanza a ver cómo pueden conectar con los apóstoles aquellas iglesias que carecen de obispos. 
La investigación sobre el Ministerio en el Nuevo Testamento ha llevado a la conclusión que el Nuevo Testamento no consagra ninguna figura ministerial. La evolución siguió una ruta concreta, cuya legitimidad no es discutible. Pero pudo haber seguido otra ruta muy distinta. Y su legitimidad tampoco se podría discutir. Al fin y al cabo, el Ministerio no tiene razón de ser en sí mismo. Está al servicio de la predicación. Si se da el caso que un Ministerio concreto, piénsese en el Ministerio episcopal, no cumple su misión y ello acontece de forma bastante general y continua, es el momento de abandonarlo y recrearlo, aunque ello conlleve marginar la denominación concreta. Dicho en otros términos: la presencia escueta de un Ministerio concreto, póngase el episcopal, no garantiza que tal iglesia sea sin más iglesia de Cristo. La presentación de la sucesión apostólica como una línea ininterrumpida de obispos es algo hoy totalmente superado en el ámbito ecuménico. Recordemos al respecto unas palabras ya citadas del documento de Accra: "La única cosa que consideran (las iglesias) incompatible con la investigación histórica y teológica contemporánea es la idea según la cual la sucesión episcopal sería idéntica a la apostolicidad de toda la Iglesia y la contendría"24.

Por lo mismo, una iglesia, que haya abandonado el Ministerio episcopal, no se puede calificar sin más ni más como no iglesia de Cristo. Hacerlo supondría el desconocimiento de los datos tanto del Nuevo Testamento, como de la evolución que en el tema se ha producido. En esta iglesia ha podido surgir un Ministerio por vía estrictamente carismática, es decir, sin ningún aval institucional. El caso concreto de Pablo avala tal posibilidad. Y el Espíritu es muy libre para salirse de los cauces que Él mismo ha creado dentro de la iglesia. El criterio para discernir si tal Ministerio tiene su fuente en el Espíritu Santo serán los frutos producidos. Lo que hizo la iglesia con Pablo y con sus escritos en su tiempo puede hacerlo con otros Ministros.

La nueva visión del Ministerio ha hecho posible que hoy se vea el Ministerio con ojos nuevos. Buen ejemplo de esto es la declaración antes recordada de los luteranos del grupo de Estados unidos y la valoración que de la misma hacen los teólogos católicos del grupo ${ }^{25}$.

En resumen se puede decir que la evolución de las figuras ministeriales, que hace ya acto de presencia en el mismo Nuevo Testamento y que se consolida hasta culminar en la figura del obispo como ministro clave, es legítima y es una confirmación de lo que aquí se defiende. Lo que sucede en la etapa

24. Documento de ACCRA. nr. 37. Seminarios 57-58, Sígueme, Salamanca, 1975, p. 565.

25. Cf. Grupo Luterano-Católico Romano. Eucaristía y Ministerio, nrs. 23.36-37. Seminarios 57-58, Sígueme, Salamanca, 1975, pp. 476. 489-490. 
posterior a la era apostólica no empaña la verdad de lo que aquí se dice, ni disminuye la flexiblidad que en el tema deja patente la investigación neotestamentaria. Flexibilidad que se traduce en posibilidad de crear nuevos ministerios y de cambiar los ya existentes, siempre y cuando ello sea necesario para que la iglesia cumpla la misión que justifica su razón de ser.

Como broche de oro a las anteriores reflexiones, cito dos párrafos del documento "Reforma y reconocimiento de los ministerios" del Instituto ecuménico alemán. Sin tener valor eclesial, poseen un gran valor técnico y científico en base a la gran competencia de los teólogos que lo han elaborado. "Las discusiones sobre la sucesión apostólica y la ordenación han sido hasta ahora obstáculos decisivos para el mutuo reconocimiento de los Ministerios y la unión de las iglesias. Como resultado de los conocimientos logrados por la teología del ecumenismo no se puede sostener ya la negativa al mutuo reconocimiento de los Ministerios, dado que las diferencias tradicionales no deben ser consideradas como motivo para la separación de las iglesias (...).

Dado que para un mutuo reconocimiento de los Ministerios no existe ya ningún inpedimento teológico decisivo, se ha superado un obstáculo importante para la plena comunidad en la cena del Señor. Allí donde se dé una fe común en la presencia de Jesús en la Eucaristía es posible una mutua admisión a la Santa Cena"26.

\section{2.- El Ministerio en el ministerio}

La frase formulada pide una aclaración. El Ministerio con mayúscula designa al Ministerio especial o Ministerio ordenado. El ministerio con minúscula se refiere al ministerio de toda la iglesia. Por lo mismo, cuando la palabra se usa con mayúscula queda bien claro qué es lo que indica. Y lo mismo, cuando se usa con minúscula.

Aclarada la terminología, comienzo la exposición. Es preciso fijarse bien en la formulación. Se dice: El Ministerio en el ministerio. Con ello se quiere expresar sin reservas que el Ministerio, sea de la categoría que fuere, episcopal, presbiteral o diaconal, no se puede entender, si no se le sitúa dentro del ministerio, es decir, de la misión de la iglesia. Al dato se refiere un significa-

26. InSTITUTOS ECUMÉNICOS AlemANES. Reforma y reconocimiento de los Ministerios, Seminarios 57-58, Salamanca, 1975, nrs. 22 y 23. p. 553. 
tivo texto del Grupo teológico luterano-católico de Estados Unidos. "La iglesia tiene por consiguiente la misión de proclamar el evangelio a todos, creyentes y no creyentes. Esta misión o servicio de toda la iglesia es llamada «ministerio» (diakonía). En el curso de esta declaración empleamos el término ministerio (con minúscula con o sin artículo definido) en este sentido. El ministerio de la iglesia entendido de esta manera se distinguirá del ( o un) Ministerio, una forma particular de servicio -en orden específico, función o carisma- que se encuentra dentro y en beneficio de la iglesia de Cristo en su misión hacia el mundo. El término Ministerio empleado en este documento se refiere a la persona a quien ha sido confiado este Ministerio. Estamos convencidos de que el Ministerio especial no puede ser discutido aparte, sino en el contexto de todo el pueblo de Dios"27.

Todo el párrafo es magnífico. Resalto las últimas frases que nos hablan de la necesidad de situar el Ministerio en el ministerio, si se quiere tener una buena visión del primero. En efecto, uno de los inconvenientes más graves en la comprensión del Ministerio es su aislamiento del ministerio. Los Ministros aparecen en esta visión como detectores de un poder que pueden ejercer a su arbitrio. Sin querer o queriendo, para su efecto es lo mismo, el Ministro hace uso de un poder y no está al servicio de una misión. En vez de ser el Ministro de la iglesia, en la iglesia y para la iglesia se convierte en el señor y dueño de la iglesia. Posee un poder mágico sobre las fuentes de la gracia que son los sacramentos hasta el extremo que tales acciones sacramentales valen en tanto en cuanto son consecuencia de un poder detentado por el Ministro.

Todo este entramado, falsamente teológico, queda desvirtuado, si se aplica el principio enunciado anteriormente. Si el Ministerio sólo es explicable en el ministerio, el Ministro, su detentor, no puede obrar por libre. Tiene que hacerlo en comunión con la iglesia. Sus actuaciones son actuaciones ministeriales en tanto en cuanto son reflejo de la misión de la iglesia. El Ministro no es un autócrata. Es un enviado, ¿qué bonita expresión?, que lleva siempre la representación de la iglesia. Vienen muy a cuento las palabras de Pablo. "Por tanto que nos tengan los hombres por servidores de Cristo y administradores de los misterios de Dios. Ahora bien, lo que se exige de los administradores es que sean fieles" (1 Cor 4,1-2).

La visión del Ministerio, que se acaba de recordar, tiene incidencias eclesiales amplias y de primera magnitud. En razón del tema, que estoy tratando,

27. Eucaristía y Ministerio, Seminarios 57-58, Salamanca 1975, nr 9, p. 471. 
voy a referirme a una sola: la sucesión apostólica. Recuérdese al respecto lo que el documento de Accra, antes citado, dice28.

Estamos, como se puede ver con facilidad, ante una cuestión trascendental eclesial y teológicamente. Con repercusiones directas en el tema que estoy tratando, ya que la unión de las iglesias exige, como requisito previo, el reconocimiento del Ministerio. Por ello, se impone tratarlo con una cierta duración.

La iglesia se confiesa en el credo apostólica. La apostolicidad es, por lo mismo, nota indispensable en la caracterización de la iglesia de Cristo. Una iglesia que, por principio, hubiese perdido tal señal, dejaría de ser iglesia de Cristo. Y ello se entiende fácilmente. Es precisamente el Ministerio apostólico el que abre el camino de acceso tanto a la persona de Jesús, como a su doctrina y su actuación. Sin el Ministerio apostólico la iglesia no hubiera sabido nada de Jesús. Jesús hubiera quedado reducido a la categoría de mito.

La condición apostólica de la iglesia pide que se dé a lo largo de la historia eso que se llama sucesión apostólica. La expresión es clara en su mensaje directo e inmediato. Hay sucesión apostólica, cuando se da continuidad entre la misión de los apóstoles y la misión de la iglesia. Hasta aquí no hay problema. El problema comienza, cuando se acomete la tarea de plasmar dicha sucesión. Normalmente tal sucesión se ha canalizado en varias iglesias a través del Ministerio. Más en concreto, del Ministerio episcopal. Según esta forma de ver las cosas, es iglesia apostólica la que cuenta con una lista de obispos que va desde hoy hasta el tiempo de los apóstoles. El concilio Vaticano II afirma: "Este santo Concilio, siguiendo las huellas del Vaticano I, enseña y declara con él que Jesucristo, eterno Pastor, edificó la santa iglesia enviando a sus apóstoles como Él mismo había sido enviado por el Padre (cf. Jn 20,21) y quiso que los sucesores de éstos, los obispos, hasta la consumación de los siglos, fuesen los pastores de su iglesia"29.

Si el tema de la sucesión apostólica se estructura sólo en base a la sucesión episcopal, parece que se cierra el camino de la apostolicidad a todas aquellas iglesias que, de una forma o de otra, han perdido el Ministerio epìscopal. Incluso, a aquéllas que, de una forma o de otra, han roto la línea de continuidad. Ello constituye un obstáculo gravísimo a la hora de hablar de la unidad de las iglesias. Y ello sucede así, porque ninguna de ellas estaría dispuesta a reconocer que su Ministerio actual pueda ser calificado de nulo.

28. Cf. nr. 37. Seminarios 57-58, Sígueme, Salamanca, 1975, p. 564

29. LG. 18 b. 
Para encontrar una salida justa y teológica al obstáculo reseñado, no queda otra alternativa que fijarse en el ministerio de la iglesia. El título colocado a este apartado es elocuente: El Ministerio en el ministerio. Lo que quiere decir que el Ministerio no se puede entender y justificar sino es en el ministerio. Alguien puede preguntar: ¿no es ésta una salida de compromiso, sin fundamento teológico y, por lo mismo, falsa? Espero ofrecer suficientes razones para concluir que no. Más aún: el contenido ofrecido en el título del apartado es el único legítimo y con valor teológico.

Pongo los ojos, en primera instancia, en la doctrina del concilio Vaticano II. Dos documentos, la Constitución dogmática sobre la iglesia y el Decreto sobre la actividad misionera de la iglesia, voy a tener presentes. Todos reconocemos que la Constitución sobre la iglesia, la Lumen Gentium, ha supuesto un giro copernicano en la eclesiología católico-romana. Aparte de presentar a la iglesia como sacramento, es decir, colocarla en el ámbito de lo mistérico y no en el ámbito de lo jurídico, cosa esta última normal en la enseñanza de la iglesia católico-romana, el concilio Vaticano II lleva a cabo una verdadera revolución eclesial, al colocar el capítulo 2 delante del 3. Lo primero que aparece es la iglesia como pueblo de Dios. Una vez asentado el principio, se desgranan todos los otros elementos de la misma. En concreto, el Ministerio en sus distintas formas.

Sólo desde este enfoque teológico es posible entender lo que el mismo Concilio afirma sobre la actividad misionera de la iglesia en el famoso decreto Ad Gentes. "La iglesia peregrinante es misionera por su naturaleza, puesto que procede de la misión del Hijo y de la misión del Espíritu Santo según el designio de Dios Padre" 30.

Ambas referencias dejan bien claro que la iglesia como tal sirve de tierra fecunda, de humus, a todo lo que en ella se mueve y se hace. Lo que afecta de forma especial al tema del Ministerio. Este no se puede entender, si se pierde de vista el horizonte eclesial. Los ministros nacen en la iglesia y viven para la iglesia. Tal prioridad eclesial queda bien afirmada en un texto del concilio Vaticano II. Dice: "El Señor Jesús ya desde el principio «llamó a Sí a los que Él quiso, y designó a doce para que le acompañaran y para enviarlos a predicar» (Mc 3,13; cf. Mt 10,142). De esta forma los apóstoles fueron los gérmenes del nuevo Israel y al mismo tiempo origen de la sagrada jerarquía"31. La construcción de la frase deja ver una cierta primacía en la visión de los doce como origen del nuevo Israel, es decir, de la iglesia. Es decir, de la doble

30. AG. 2.

31. AG. 5 a. 
faceta de su significado se resalta la primera. La iglesia, por lo mismo, es el marco referencial imprescindible, cuando se hace memoria de los Ministros.

Este enfoque del tema aparece claramente reseñado en los documentos que tratan el tema de la unidad de las iglesias. Escuchemos algunos textos significativos. "Estamos convencidos de que el Ministerio especial no puede ser discutido aparte, sino en el contexto del ministerio de todo el pueblo de Dios"32.

"La misión común de la iglesia, atestiguada por el evangelio, es confiada a cada fiel por el bautismo de agua y del Espíritu, y por su participación en la eucaristía.

Cada miembro del cuerpo de Cristo está llamado y habilitado para vivir su fe y para dar testimonio de ella en medio de sus hermanos por el servicio del amor y de la justicia, por la irradiación de la esperanza. Así, en cada lugar, la comunidad cristiana da testimonio de la reconciliación, que ella vive y llama a todos los hombres a dejarse reconciliar con Dios y entre ellos.

En todo tiempo y lugar la iglesia, pueblo de Dios, es, a pesar de su miseria, «una raza elegida, un sacerdocio real, una nación santa, un pueblo adquirido para anunciar las alabanzas de Aquel que llama «a los hombres a su luz» (1 Petr 2,9).

La evangelización, el servicio al mundo por la iglesia, la edificación de la comunidad requieren actividades muy diversas, permanentes o momentáneas, espontáneas o institucionales" 33 .

"El ministerio ordenado debe ser entendido como un elemento de la comunidad: para comprender el ministerio, es pues necesario partir de la naturaleza de la iglesia, comunidad de creyentes. La mayoría de las iglesias comparten hoy esta convicción. Es por esto por lo que las consideraciones que siguen tienen como punto de partida a la comunidad cristiana; después, intentan definir la naturaleza y las funciones del ministerio ordenado a la luz de esta comunidad" 34 .

Tras estas citas, tomadas todas ellas de fuentes oficiales o cuasi-oficiales, parece oportuno recordar la opinión de algún teólogo representativo en el tema. Por su solvencia y equilibrio escojo al P. Congar. Después de recordar cómo se había vivido el tema en el interior de la iglesia católico-romana, iglesia que se ha distinguido siempre por una fuerte impronta jerárquica, afirma:

32. Grupo teológico Luterano-Católico de Estados Unidos, Eucaristía y Ministerio, Seminarios 57-58, Salamanca, 1975, nr 9, p. 471.

33. GRUPO DE DOMBES, para una reconciliación de los ministerios, Seminarios 57-58, Salamanca, 1975 , nrs. $14,15,16,17$, pp. 537-538.

34. Documento de Accra, Seminarios 57-58, Salamanca, 1975, nr. 2, p. 557. 
"La entrada por la puerta y el concepto de comunidad sería más satisfactoria. Huiríamos así de dos concepciones desafortunadas: igualmente desafortunadas, además. No sería el esquema lineal (Cristo-Sacerdocio-fieles), con el peligro de hacer del Sacerdocio jerárquico una mediación que supondría un pueblo menor, impotente y pasivo. No sería una especie de democratismo que los protestantes no profesan, aunque a veces algunas expresiones suyas podrían inquietar («devolución», por ejemplo); porque no hacen de los ministros puros delegados de la comunidad; sostienen que Dios ha querido y, en este sentido, instituido ministerios, pero de manera global, de suerte que no se puede deducir del Nuevo Testamento un tipo de organización que se impusiera iure divino de forma absolutamente normativa. Son las iglesias las que, por su disciplina, organizan estos ministerios teniendo en cuenta lo que la Escritura puede decir al respecto (...)"35.

El nuevo horizonte ideológico, suficientemente retratado en las líneas anteriores, abre una puerta firme y segura para poder acceder a una nueva forma teológica de ver la sucesión apostólica. La nueva forma de entender la sucesión apostólica se apoya en la visión bíblicamente más correcta de la iglesia como comunidad envolvente. Todo lo que se venía diciendo en este campo sobre el Ministerio se traslada ahora a la iglesia como comunidad. Cuando, por ejemplo, Jesús resucitado encomienda a los Once que vayan por el mundo, prediquen el evangelio y hagan discípulos suyos en todos los pueblos, (cf. Mt 28,18bss; Mc 16,15b), los Once son, ante todo y sobre todo, el germen del nuevo pueblo de Dios o, si se quiere mejor, son la iglesia de entonces. La misión se recibe como comunidad y no tanto como sujetos del Ministerio.

Tenemos así la clave para abordar ya el tema de la sucesión apostólica. Si nos preguntamos ¿quién sucede a los apóstoles?, la respuesta no puede ser más que ésta: la iglesia. Hans Küng ilustra el tema en forma bien contundente. "Los apóstoles murieron; no hay nuevos apóstoles, pero la misión apostólica permanece. La misión apostólica no se recibe ya inmediatamente del Señor, sino que se realiza por medio de los hombres. Y en razón de la misión apostólica permanente, permanece el servicio apostólico. Pero este servicio apostólico no se cumple en cuanto alguien es llamado nuevamente al apostolado, sino por obediencia a los apóstoles como testigos y heraldos primigenios del Señor. Por razón, pues, de la misión apostólica permanente, hay en el servicio apostólico una sucesión apostólica, una sucesión apostólica en la obediencia. Intencionadamente no hablamos de apostolica succesio. Los pro-

35. Ministerios y comunión eclesial, Ed. FAX, Madrid, 1973, p. 20. 
blemas teológicos no deben obnubilarse con ideas secundarias, jurídicas y sociológicas. Nuestra pregunta, en cambio, es: ¿Quién sucede a los apóstoles? (...)

La respuesta fundamental sólo puede ser una: la iglesia. No algunos particulares; la iglesia entera sucede a los apóstoles. ¡Confesamos la iglesia apostólica! En efecto, la iglesia entera es el nuevo pueblo de Dios congregado por los apóstoles por medio de la predicación del evangelio de Jesucristo. La iglesia entera es el templo del Espíritu, construido sobre el fundamento de los apóstoles. La iglesia entera es el cuerpo de Cristo que se mantiene unido por el ministerio de los apóstoles. Así pues, la misión con plenos poderes de los apóstoles ha pasado a aquella iglesia que los apóstoles congregaron; el ministerio con plenos poderes de los apóstoles ha pasado a aquella iglesia a la que sirvieron los apóstoles. La iglesia es, en la obediencia, la sucesora de los apóstoles"36.

Esta visión de la sucesión apostólica, avalada bíblica y magisterialmente, no disminuye en nada la sucesión que se da en el Ministerio. Podemos y debemos mantener que los obispos u otros ministros legítimos son sucesores de los apóstoles. Simplemente la sitúa en el marco de referencia que nunca se debe perder de vista, si no se quiere caer en el grave error de ver a los ministros como detentores de poderes autónomos. $\mathrm{O}$, si se quiere, usando otra fórmula parecida, aunque más fuerte, si se desea evitar la presencia en la iglesia de unos ministros que actúan por su cuenta y a su antojo. Supondría un error eclesiológico de magnitudes estelares pensar tal cosa. El ministro aparecería en esta concepción como un ser al margen y por encima de la iglesia. Lo que constituye algo incompatible con una eclesiología de pueblo de Dios. Y además tal visión estaría fuera de lo que históricamente se ha dado en el proceso del desarrollo eclesial.

La historia confirma que tales extremos, que hoy nos parecen impensables y absurdos, han tenido presencia muy viva en nuestra iglesia. La visualización de la sucesión apostólica en exclusiva desde el Ministerio, más en concreto desde el Ministerio episcopal, condujo como de la mano a una eclesiología de cuño jerárquico. Oigamos el testimonio sobrecogedor del siempre admirado P. Congar: "A pesar de interesantes incentivos de renovación, de que trataremos más adelante, la iglesia era presentada hacia 1930 (fecha de mi ordenación sacerdotal) como una sociedad organizada, que se constituía por el ejercicio de poderes de los que el papa, los obispos y los sacerdotes estaban investidos. La eclesiología consistía casi exclusivamente en un trata-

36. La iglesia, Herder, Barcelona, 1970, pp. 423-424. 
do de derecho público. Yo creé, para caracterizarla, la palabra «jerarcología» que con frecuencia se ha venido usando después"37.

El mismo P. Congar recuerda al respecto unas afirmaciones del papa Pío $\mathrm{X}$ que, aunque se sitúen en su tiempo, no dejan de llamar profundamente la atención. " «En la sola jerarquía residen el derecho y la autoridad necesaria para promover y dirigir a todos los miembros hacia el fin de la sociedad. En cuanto a la multitud no tiene otro derecho que el de dejarse conducir y, dócilmente, el de seguir a sus pastores». Es claro que el enunciado supone determinado contexto; pero difícilmente se podría leer hoy en un documento pontificio"38.

La consecuencia más negativa de la eclesiología jerárquica fue un laicado subdesarrollado y pasivo. Los enfoques equivocados tienen siempre consecuencias desastrosas. Esto es lo que sucedió en nuestra iglesia. Ahora el problema está teóricamente solucionado. El concilio Vaticano II, haciéndose eco de lo que ya estaba en el ambiente, ha ofrecido un modelo de eclesiología integral de tal modo que todos los miembros de la iglesia, eso sí cada uno con su carisma propio, pueden y deben tener una participación activa en la labor misionera de la iglesia. El logro de lo que significa esta nueva cara de la eclesiología tardará mucho tiempo en alcanzarse. Las personas no cambian de la noche a la mañana. Con todo, hay que reconocer que se han dado pasos de gigante. Hoy se cuenta con suficientes términos teológicos, como para hablar de una eclesiología envolvente, en donde todos tienen algo que decir y hacer.

Entre tales principios teológicos se halla lo que se enunció en este apartado. El Ministerio sólo es inteligible en el ministerio. La sucesión apostólica de los ministros sólo se puede explicar desde la visión de la iglesia como sucesora de los apostóles.

Hay otro punto en el tema que no puede quedar en la penumbra. Se trata de la visión de la sucesión apostólica desde la perspectiva de la doctrina. Cuando la sucesión apostólica se canalizaba a través del Ministerio, se corría el riesgo, y más que hablar de riesgo hay que hablar del hecho, de cargar los tintes en lo puramente jurídico y lineal. Una iglesia era iglesia de Cristo, si podía contar con una sucesión ininterrumpida de ministros. Línea que, por lo mismo, se remontaba hasta los apóstoles. No se tenía en cuenta, si tal iglesia predicaba o no el evangelio. Con todo lo que pueda tener de pasión y, por lo mismo, con la necesidad de ejercer un juicio crítico, Lutero habla del tema en

37. Ministerios y comunión eclesial, FAX, Madrid, 1973, p. 12.

38. Ib. p. 14. 
términos verdaderamente impresionantes. "Si los obispos lo fuesen de verdad y se decidiesen a atender a la iglesia y al evangelio, por motivos de caridad y de unidad -pero no por una necesidad- se les podría permitir que ordenasen y nos confirmasen a nosotros y a nuestros predicadores, con tal de que prescindiesen de todas las apariencias y fantasmagorías de una pompa que nada tiene de cristiano. Pero no son obispos verdaderos ni desean serlo; mejor estaría decir que son señores y príncipes seculares, a quienes no interesa predicar, ni enseñar, ni bautizar, ni administrar la santa cena, ni ejercer obra ni ministerio por su vocación. Por eso, la iglesia no tiene que prescindir de sus ministros a causa de los obispos"39. Es verdad que Lutero refleja un momento concreto y que su veredicto no puede universalizarse. En su tiempo había obispos santos y celosos que cumplían fidelísimamente con la misión recibida. Mas lo que interesa del texto es el fondo del mismo. Cuando los obispos no cumplen con su misión, cuando no ofrecen a su pueblo la verdad del evangelio, entonces han corrompido su razón de ser. Y, por ello y desde esta perspectiva, no se puede decir que están en la sucesión de los apóstoles. Son pseudo-sucesores de los apóstoles, aunque les acompañen todos los requisitos canónicos. Son, para usar la imagen evangélica, lobos con piel de oveja (Mt 7,15).

Los documentos ecuménicos, vengan de donde vinieren, resaltan el dato. Simplemente, y como muestra, voy a citar al documento de Accra. "La manifestación principal de la sucesión apostólica se encuentra en toda la vida de la iglesia. Esta sucesión es una expresión de la permanencia y, por esto mismo, de la continuidad de la misión de Cristo en la cual participa la iglesia. Esta participación está enraizada en el don del Espíritu Santo, en el envío de los apóstoles y de sus sucesores, y encontrará su perfección en la realización total del reino de Dios.

La plenitud de la sucesión apostólica de toda la iglesia implica la continuidad de los caracteres permanentes de la iglesia de los apóstoles: el testimonio de la fe apostólica, la proclamación y la interpretación actual del evangelio apostólico, la transmisión del cargo ministerial, la vida sacramental, la comunión del amor fraternal, el servicio junto a los necesitados, la unidad entre las iglesias locales y el reparto de los dones que el Señor ha dado a cada uno"40.

39. Egido. T., Lutero, obras. Sígueme, Salamanca, 1977, p. 355.

40. Fe y Constitución. Documento de Accra, Seminarios 57-58, Salamanca, 1975, nrs. 27,28 p. 563. 
Puedo cerrar este apartado, rico en contenido, con la seguridad de que el Ministerio sólo es inteligible en el ministerio, tal como rezaba le título. Se recupera así el valor del Ministerio para la apostolicidad de la iglesia. Pero, sobre todo, se sitúa en su justo punto y se des-absolutiza. Todo ello muy importante, si se tiene en cuenta el horizonte ecuménico de estas reflexiones.

\section{3.- Importancia de la eclesiología local en el tema}

De todos, al menos de los que se interesan por la teología, es conocido que el Ministerio episcopal es un Ministerio local. Que, además, es el Ministerio más importante en algunas iglesias, entre las que hay que recordar por su importancia a la iglesia católico-romana, a la iglesia ortodoxa y a la iglesia anglicana. Ello impone la tarea de dedicar unas reflexiones a la iglesia local.

De entrada hay que afirmar que la eclesiología local tiene profundas raíces bíblicas. Pablo comienza sus cartas con fórmulas que indican claramente que la iglesia de Dios o de Cristo se encuentra en un lugar determinado. "A la iglesia de Dios que está en Corinto" es la expresión más significativa del tema. Hay otros saludos que tienen idéntico significado. La carta a los Filipenses comienza así: "Pablo y Timoteo, siervos de Cristo Jesús, a todos los santos en Cristo Jesús, que están en Filipos, con los epíscopos y diáconos. Gracia a vosotros y paz de parte de Dios nuestro Padre y del Señor Jesucristo" (1,1-2). Todo ello es indicio claro que, según el pensamiento de Pablo, la iglesia de Cristo se realiza allí en donde vive una comunidad reunida en su nombre y dirigida por unos ministros. Tal iglesia es completa en su ser y en su vivir.

Si se tomara ahora la tarea de descubrir el fundamento de tal forma de ver la iglesia, no queda otro camino que acudir a la relación que Pablo establece entre iglesia y celebración eucarística. La palabra clave es cuerpo. Iglesia y eucaristía convergen en ella. "Ahora bien, vosotros sois el cuerpo de Cristo" (1 Cor 12, 27a). "Este es mi cuerpo", dice hablando de la eucaristía (1 Cor 11,24b). El cuerpo de Cristo no puede estar mutilado ni en la iglesia, ni en la eucaristía. Por lo mismo, si dicho cuerpo está entero en el sacramento de la eucaristía, también tiene que estarlo en la iglesia, que la celebra y da sentido.

Como aporte ecuménico al tema es preciso recordar algunos textos muy en línea con tal eclesiología. La Comisión mixta internacional de Diálogo teológico entre la iglesia católico-romana y la iglesia ordoxa dice: "El cuerpo de Cristo es único. No existe, pues, más que una iglesia de Dios. La identidad de una asamblea eucarística con otra viene de que todas, con la misma fe, 
celebran el mismo memorial; de que todas, al comer el mismo cuerpo de Cristo y participar del mismo cáliz, se convierten en el mismo y único cuerpo de Cristo, en el que han sido integradas por el mismo bautismo. Si hay multiplicidad de celebraciones, no hay más que un solo y único misterio celebrado en el que se participa. Además, cuando el fiel comulga el cuerpo y la sangre del Señor, no recibe una parte de Cristo, sino el Cristo total.

De la misma manera la iglesia local que celebra la eucaristía en torno al obispo, no es una sección del cuerpo de Cristo. La multiplicidad de synapsis locales no divide a la iglesia, sino al contrario, manifiesta sacramentalmente su unidad. Como la comunidad de los apóstoles reunidos alrededor de Cristo, cada asamblea eucarística es, en verdad, la santa iglesia de Dios, el cuerpo de Cristo, en comunión con la primera comunidad de discípulos y con todas aquellas que en el mundo entero celebran y han celebrado el memorial del Señor. Está también en comunión con la asamblea de los santos en el cielo, que cada celebración evoca"41.

El documento de Dombes sobre el Ministerio episcopal presenta también bellos pensamientos sobre el tema. "Una iglesia nace y crece allí en donde unos hombres, bajo la acción del Espíritu Santo, se convierten al evangelio y se reúnen en comunidades.

Para que este agrupamiento corresponda a lo que nosotros llamamos «iglesia particular» en la que se ejerce en un lugar dado la episkopé sobre un conjunto de parroquias y de comunidades, deberán responder a las características siguientes:

- une hombres de toda edad, origen y condición para hacer de ellos un pueblo, testigo del Evangelio en el mundo que le rodea;

- todas las funciones de la iglesia son ejercidas allí, principalmente el anuncio de la Palabra de Dios y la celebración del culto y de los sacramentos;

- acoge los ministerios necesarios para la edificación y la misión de la iglesia;

- recibe del Espíritu Santo nuevos ministros que son ordenados en su seno;

- vive en comunión visible con otras iglesias"42.

El reconocimiento del valor teológico de la iglesia local como presencia viva de la iglesia de Cristo y portadora en su seno del Ministerio de la epis-

41. El misterio de la iglesia y de la eucaristía a la luz del misterio de la Santísima Trinidad, en Enchiridium Oecumenicum Y, Salamanca 1986, nr 3a y b, p. 510.

42. GRuPo DE DOMBES. El ministerio episcopal, Enchiridium Oecumenicum, Salamanca, 1986, nr.9, p. 674 . 
kopé parece conllevar un modo distinto de hablar de la iglesia universal. Tengo la impresión que, cuando se habla de la iglesia universal, se piensa en una realidad que sobrevuela a la iglesia particular. $Y$ las cosas no parecen ser así. La iglesia universal no es una realidad que esté por encima de las iglesias particulares. Nace no por añadidura, sino por comunión de las iglesias particulares. Lo que es verdaderamente bello. Así la iglesia universal se hace icono de la Trinidad. "La iglesia viene de la Trinidad, camina hacia ella y está estructurada a su imagen; todo lo que el concilio dijo de la iglesia está compendiado en esta memoria del origen, de la forma y del destino trinitario de la comunión eclesial. El árido visibilismo del pasado no podía ser superado de manera más radical: la fidelidad a la historia no podía expresarse con una exigencia más imperiosa. La iglesia del concilio es -en continuidad con el testimonio de la Escritura y de los Padres- la iglesia de la Trinidad, la «ecclesia Trinitatis»" $" 43$

La eclesiología trinitaria y eucarística, tan cara a la teología ortodoxa, es un buen punto de referencia a la hora de hacer una reflexión sobre el Ministerio del obispo. Intento aprovechar ese doble foco de luz para conseguir alcanzar la meta. En la iglesia local hay un Ministerio, la episkopé, y un ministro, el obispo, que encarna la episkopé de forma relevante. La episkopé, como tarea, discurre por tres sendas, que, aunque diversas, se complementan. Se trata de la misión de predicar la palabra de Dios, administrar los sacramentos y presidir a la comunidad cristiana. El concilio Vaticano II habla del tema en términos sugestivos. "Entre los oficios principales de los obispos se destaca la predicación del evangelio. Porque los obispos son los pregoneros de la fe que ganan nuevos discípulos para Cristo y son los maestros auténticos, es decir, herederos de la autoridad de Cristo, que predican al pueblo que les ha sido encomendado la fe que ha de creerse y ha de aplicarse a la vida, la ilustran con la luz del Espíritu Santo, extrayendo del tesoro de la revelación las cosas nuevas y las cosas viejas (cf. Mt 13,52), las hacen fructificar y con vigilancia apartan de la grey los errores que la amenazan (Cf. 2 Tim 4,1-4) (...)

El obispo, revestido como está de la plenitud del sacramento del orden, es el «administrador de la gracia del supremo sacerdocio» sobre todo en la eucaristía que él mismo distribuye, ya sea por sí, ya sea por otros, y hace vivir y crecer la iglesia (...)

Los obispos rigen, como vicarios y legados de Cristo, las iglesias particulares que se les han encomendado, con sus consejos, con sus exhortaciones,

43. Forte, B., La iglesia icono de la Trinidad, Pedal, Sígueme, Salamanca, 1992, p. 31. 
con sus ejemplos, pero también con su autoridad y con su potestad sagrada, que ejercitan únicamente para edificar su grey en la verdad y la santidad, teniendo en cuenta que el que es mayor ha de hacerse como el menor y el que ocupa el primer puesto como el servidor (cf. Lc 24,26-27)"44.

La triple tarea en que se desglosa la episkopé, recordada por el concilio Vaticano II, se recoge prácticamente en todos los documentos de carácter ecuménico. Cito algunos más significativos. El documento de Accra afirma: "La función esencial y específica del ministerio particular es: reunir y construir la comunidad cristiana, proclamando y enseñando la Palabra de Dios, presidiendo la vida litúrgica y sacramental de la comunidad eucarística (...)

La selección para el ministerio particular implica a la vez consagración al servicio y autoridad para ejercerlo. Puesto que todo ministerio está enraizado en el de Jesucristo, su cualidad esencial viene ilustrada por las palabras de Jesús: «Yo estoy entre vosotros como el que sirve» (Lc 22,24). La misión que Cristo ha dado a sus apóstoles se sitúa bajo esta luz: «Como Tú me has enviado al mundo, dice Jesús al Padre, así los he enviado yo al mundo; por ellos me santifico yo mismo, a fin de que ellos sean también santificados en la verdad (Jn 17, 18-19). Y san Pablo acepta así su ministerio de apóstol, que lo describe como una participación en la pasión de Cristo: «nosotros llevamos por todos los sitios y siempre los sufrimientos y muerte de Jesús, para que la vida de Jesús sea también manifestada en nuestro cuerpo» (2 Cor 4,10)"45.

El Grupo de Dombes, muy representativo por lo variado de sus miembros, habla de la episkopé en términos admirables. "La fe es suscitada y la iglesia constituida por la predicación del evangelio (Rom 10,17). Al reunir la iglesia, Cristo «soberano Pastor» (1 Petr 5,4), le da un ministerio de vigilancia que asegura el anuncio de la palabra, la celebración de los sacramentos, la diaconía y las otras funciones del cuerpo de Cristo, su soberanía y su unidad.

Según los diversos testimonios del Nuevo Testamento, el ministerio de la episkopé se ejerce siguiendo a Cristo «epíscopo de nuestras almas» (1 Petr 2,25), y siguiendo a los Apóstoles, en lo que su cargo tiene de transmisible. Consiste en conducir el rebaño, velar por él, informarle, exhortarle (Hech 20,28-31), censurar (1 Cor 5,3-5) y animar a la comunidad con vistas a su misión universal. Este ministerio de dirección y de presidencia no existe sólo para el servicio interno de las comunidades: orienta la reunión de los fieles en su apertura al mundo y su marcha hacia el reino.

44. LG. 25a, 26a, 27a.

45. Fe y Constitución. Documento de Accra, Seminarios 57-58, Salamanca, 1975, nrs. 15a, 17 p. 569. 
Un cierto número de otros textos bíblicos contribuye a definir esta forma de ministerio: transmisión y guarda del depósito (Tit 2,1 7-8; 2 Tim 1,14 y 2,2), presidencia de las comunidades ( 1 Tim 5,17$)$; discernimiento de los carismas (1 Petr 4,10)"46.

La tarea de la episkopé, que, como se acaba de ver, es esencial a la razón de ser de la iglesia, exige ministros que la lleven a cabo. Es cierto que en su ejecución todos los miembros de la iglesia están implicados. Así se desprende de la enseñanza del concilio Vaticano II principalmente en el decreto $A d$ gentes. "La iglesia peregrinante es misionera por su naturaleza" 47 . El documento de Dombes sobre el ministerio episcopal afirma a su vez: "En la docilidad al Espíritu Santo, la fidelidad a Cristo y la obediencia al Padre, todos los cristianos ejercen sus carismas y sus funciones solidariamente para el bien del cuerpo de la iglesia y de su misión"48.

Sin olvidar nada de lo dicho, es preciso reconocer que la tarea de la episkopé conlleva la exigencia de ministros que se entreguen a la misma y la hagan eficaz. Los primeros ministros de la misma, vinculados directa y próximamente al ministro de los ministros, «al epíscopo de nuestras almas» (1 Petr $2,25)$, fueron fundamentalmente los apóstoles. Desaparecidos ellos, es preciso, y así nos lo dice el Nuevo Tesmento, que otros tomen su relevo. "Testimonios neo-testamentarios presentan a los Apóstoles estableciendo en las iglesias presbíteros-epíscopos por la imposición de manos (Hech 14,23; Tit 1, 5-7) y confiando a hombres seguros la tradición de la enseñanza evangélica (1 Tim 1,3-7; 2 Tim 4,1-5)"49.

La evolución ministerial, presente ya en el Nuevo Testamento y activa particularmente en el siglo II, termina por consagrar una de sus figuras: la del obispo. En cada iglesia hay un obispo, que es el ministro principal de la episkopé. Le ayudan en esta misión un grupo de presbíteros y de diáconos. Y, si se entienden bien las cosas, toda la comunidad cristiana tiene su parte en la episkopé. Dado el relieve de la figura ministerial del obispo, se entiende fácilmente que nazca sobre la misma una rica y variada teología. Los rasgos más sobresalientes de la misma son los siguientes:

46. GRUPO DE DOMBES. El ministerio episcopal, En Enchiridium Oecumenicum I, Salamanca 1986 , nrs.15,16,17 p. 675-676.

47. AG. nr. 2.

48. GRUPo DE DOMBes. El ministerio episcopal, En Enchiridium Oecumenicum I, Salamanca, 1986, nr. 32, pág 679.

49. GRUPO DE DOMBES. El ministerio episcopal, Enchiridium Oecumenicum I, Salamanca, 1986, nr. 24, pág 677. 


\section{a.- Su elección}

\section{b.- Su significado hacia dentro y hacia afuera}

Antes de entrar en la exposición de estos dos apartados o temas, debo afirmar que no tengo intención de juzgar y menos de recriminar costumbres eclesiales que no se ajusten a lo que voy a decir. En temas como éste los modos exclusivistas no deben tener la última razón. Tan sólo quiero expresar lo que parece ser el camino más correcto para que el ministerio episcopal, tan importante, adquiera todo su relieve y pueda servir mejor a la tarea de la episkopé. Y, desde aquí, poder alzarse como figura ministerial a mantener o recuperar en una futura unión, ¡ojalá no lejana!, de las iglesias. Mi discurso se articula un tanto en la línea delicada del documento de Dombes sobre el ministerio episcopal. Dice: "Hemos intentado recuperar a través de la experiencia de las primeras comunidades de que habla la Escritura la intención de Cristo relativa a la naturaleza de la episkopé en la estructura de su iglesia. Esta episkopé asocia la colegialidad a la presidencia personal.

Ser fiel a la intención de Cristo consiste en respetar esta estructura sin intentar sacar del Nuevo Testamento un modelo de organización único y normativo. Con mayor motivo no vamos a erigir en normas ciertas posturas confesionales que resultan de contigencias históricas; ni a dejarnos dictar, por influencias sociológicas contemporáneas, los elementos visibles de la iglesia" 50 .

\section{a.- Su elección}

El tema de la elección de obispos es un tema de trascendental importancia. Y lo es, entre otras cosas, por dos motivos muy significativos. Uno, de carácter personal. Otro, de carácter pastoral y, si se quiere, teológico. Para hacer efectivos dichos motivos, es preciso cambiar la forma de su elección. Todos sabemos que en la iglesia católica los obispos son, en última instancia, elegidos por el papa. No es del caso traer a cuento qué mecanismos actúan para hacer efectiva una elección episcopal. Sin descalificar esta fórmula de elección, creo que todo el entramado personal y misional está pidiendo un cambio. Desde el aspecto personal, que, a primera vista tiene escasa importancia, mas no es así, la elección es, de alguna manera, impuesta. Ello conlleva graves inconvenientes para el mismo obispo. Éste adviene a su comunidad

50. Ib. nrs. 31a y b, p. 679 . 
casi siempre desde fuera y casi siempre totalmente desconocido para la misma y desconocedor de la misma. El tiempo, que discurre entre la llegada y el momento en que el obispo logra estar en condiones de saber en dónde se encuentra y conocer medianamente la comunidad, siempre compleja, a la que sirve, tiene que ser para el obispo de una gran tensión interior.

Tal sufrimiento interior es perfectamente evitable, si la comunidad, a la que el obispo va a servir, si la comunidad en la que va a ejercer la episkopé, es la autora de la elección o, por lo menos, tiene parte activa en la misma.

A lo que hay que añadir que esta forma de elección tiene cualidades pastorales y teológicas de no fácil captación en la forma actual. La relación del obispo con su comunidad es una relación que se puede perfectamente asemejar a la relación esponsal. El anillo que lleva es su signo más brillante. Pues bien, hoy resulta impensable que en una cultura desarrollada se imponga a la esposa su esposo o que la esposa no tenga la facultad de elegir esposo. La sensibilidad moderna avala así un dato que tiene valor teológico altamente significativo.

En tiempos pasados las cosas discurrieron por este camino. Es verdad que relativamente pronto algunos Metropolitanos, dignidad eclesiástica nueva, defendían el derecho de nombrar a «sus» obispos. El papa León Magno condena tal práctica. Escribiendo a uno de ellos, le dice: "No es lícito a ningún Metropolitano consagrar obispo a alguien por su cuenta, sin contar con el consentimiento del pueblo y del clero, sino que se debe poner al frente de la iglesia al que haya elegido toda la ciudad"s1.

En otro texto significativo León Magno insiste en lo mismo, añadiendo algunos detalles de gran sensibilidad humana: “Al que es conocido y aprobado se le reclama con paz; al desconocido es preciso imponerlo por la fuerza; (...) el que ha de presidir a todos, que sea elegido por todos, ya que lo contrario será siempre «materia de disensión»"s2.

González Faus hace un comentario sabroso al tema. "Que estas frases no debían de ser pura teoría, lo comprobamos por el ejemplo de Inocencio I a comienzos del siglo V. Este papa creyó necesario intervenir para evitar que las provincias eligiesen obispo a un hombre de pésima fama y que podía ser un verdadero criminal. Ante situación tan límite, el papa interviene. Pero su intervención se limita a ser una recomendación a los obispos y al pueblo de aquella provincia en el sentido de que elijan a alguien mejor y más seguro. De 
ningún modo les impone él a un candidato, sino que vuelve a dejar la elección en manos de aquellas iglesias" 53 .

La participación de la comunidad en la elección de su obispo refleja, de una forma difícil de descubrir en otra forma de elección, la relación profunda que se da entre detentor de un Ministerio y la comunidad a la que sirve. Se aborda en este momento uno de los temas más espinosos en el tema. Me estoy refiriendo a las ordenaciones absolutas. Lo hago en forma de pregunta: ¿Tiene sentido ordenar obispos sin que haya una comunidad a la que servir o en la que ejercer la episkopé? Dicho en forma equivalente: ¿Tienen sentido las llamadas ordenaciones absolutas? Un primer paso a dar en la respuesta tiene carácter histórico. El canon 6 del concilio de Calcedonia no sólo prohibe tales ordenaciones, sino que las considera inválidas. Recojo este famoso canon: "Nadie puede ser «ordenado» absolutamente (apolymenós) ni como sacerdote, ni como diácono (...) Si no se le asigna claramente una comunidad local en la ciudad o en el campo, en un martirium (sepultura de un mártir venerado) o en un monasterio; en ese caso, «el sacratísimo concilio determina que su cheirotonia (ordinatio o nombramiento) es nula o inválida (...) y, por tanto, no puede realizar funciones en ninguna ocasión"54.

E. Schillebeeckx, de quien he tomado la cita, añade a renglón seguido: "Este texto revela una concepción clara del ministerio en la iglesia. Sólo aquél que ha sido llamado por una comunidad concreta (el pueblo con sus dirigentes) para que la presida y dirija recibe la ordinatio (de forma intencionada renunciamos a traducir este término por ordenación). La ordinatio es la integración o «incorporación» ministerial en una comunidad, que llama a un cristiano y lo elige como presbítero de la misma (o, como ocurría especialmente en la época más antigua: acepta y confirma oficialmente la actividad carismática de uno de sus miembros). Una <ordinatio absoluta», es decir, aquella ordinatio en la que se impongan las manos a alguien que no haya sido propuesto por la comunidad concreta para que sea su presidente, es nula o inválida. Se manifiesta aquí una concepción marcadamente eclesial del ministerio"55.

En atención a estos datos tan significativos desde todos los puntos de vista las preguntas antes formuladas parece que no admiten más que una respuesta: no. No tienen sentido las ordenaciones absolutas y, para que tales ordenaciones sean coherentes con la misión a llenar, toda la comunidad, si no

53. Hombres de la comunidad. Apuntes sobre el ministerio eclesial. Sal terrae, Santander, 1989, p. 127.

54. PG. 104,558

55. El ministerio eclesial. Responsables en la comunidad cristiana.Ed. Cristiandad, Madrid, 1983, p. 78. 
de forma masiva, sí de forma significativa, debe intervenir en la elección de sus dirigentes.

Todo esto choca con la praxis actual vigente en la iglesia católica. Y, por lo mismo, alguien puede creer que yo estoy descalificando tal praxis. No es mi intención hacerlo. Estoy recordando un hecho histórico que, según todos los indicadores salidos de distintos puntos, apuntan a la necesidad o, al menos, la conveniencia de recuperar algo que está en una línea mucho más coherente con la naturaleza del ministerio eclesial. "Se manifiesta aquí una concepción marcadamente eclesial del ministerio", decía Schillebeeckx en el párrafo citado. No se olvide que este artículo es una reflexión sobre el Ministerio episcopal como Ministerio a mantener o a recuperar en una futura unión de las iglesias. Para que ello tenga aceptación universal dicho Ministerio debe ser sometido a todas aquellas purificaciones que, de alguna manera, han desfigurado su cara apostólica.

Culmino el apartado con una cita un tanto larga del mismo Schillebeeckx. "La comunidad tiene un derecho -que es gracia- a poseer dirigentes. Por eso (unida siempre a los que actúan ya como dirigentes) toma la iniciativa ella misma. Por otra parte, en la primera época de la iglesia, cada comunidad local era consciente de que poseía todos los elementos necesarios para que una «comunidad de Cristo» llevase a cabo su propia edificación y vida (en este terreno no existían aún las reservas impuestas desde arriba). La iglesia local es quien llama a sus propios ministros. El lazo esencial entre comunidad y ministerio, formulado en términos jurídicos en Calcedonia, es un índice que en aquella época la diferencia entre potestad de orden y potestad de jurisdicción no sólo era desconocida, sino además eclesiológicamente inimaginable. El ministerio es algo que interesa a la comunidad local. Cipriano reclamará este derecho incluso frente al papa Esteban, considerándolo como un derecho de origen divino, es decir, algo que pertenece a la esencia de una «comunidad de Dios». «Que no se le impoga al pueblo un obispo que el pueblo no desea». El mismo León Magno formulará este principio lapidariamente: "Aquél que debe presidirlos a todos debe ser elegido por todos»"56.

56. El ministerio eclesial. Responsables en una comunidad cristiana.Ed. Cristiandad, Madrid, 1983, p. 80 


\section{b.- Su significado hacia adentro y hacia afuera}

El significado de la figura del obispo, cuya vinculación a la comunidad ha sido calificada en el estudio como esponsal, es de importancia capital. Y tiene como dos caras; si se quiere, se manifiesta en dos proyecciones: hacia adentro y hacia afuera. Hacia adentro el obispo representa ante todo la unidad. La iglesia es una y el obispo es la figura que encarna y representa de manera particular esa cualidad. La comunidad, agrupada alrededor del obispo, es un misterio de unidad, cuyas dos manifestaciones más significativas giran alrededor de ser imagen, icono de la Trinidad, y la celebración eucarística presidida por el obispo o alguien en su nombre.

Hacia afuera el obispo es el signo de la koinonía. Digamos en castellano: de la comunión. El dato me parece estar cargado de un simbolismo extraordinario. Algo apuntaba antes, cuando decía que la iglesia universal no es tanto una realidad que sobrevuele a las iglesias locales, sino una realidad que nace de la comunión entre las iglesas locales. Y ello no por añadidura, sino precisamente por comunión.

Un manifestación espléndida de la realidad en cuestión es la forma en que se celebra la consagración episcopal. Dicha consagración se hace siempre por un obispo consagrante acompañado de otros dos. Con ello se quiere expresar la comunión que hay entre los obispos, anticipo y retrato de la comunión que debe haber entre las iglesias que ellos representan.

La manifestación más relevante de esta realidad es el concilio ecuménico. La reunión de todos los obispos en asamblea solemne, es decir, en concilio ecuménico, se hace no desde el individualismo, sino desde la comunidad. Los obispos no están en concilio ecuménico como personas individuales, sino como representantes de sus respectivas comunidades. Por eso, el concilio ecuménico es la congregación de toda la iglesia nacida de la propia comunión de las iglesias. Y, aunque son los obispos quienes hablan en el concilio ecuménico, la voz última es la de las iglesias, a las que representan y por las que fueron enviados.

Hay otras varias formas de expresar dicha comunión. Siempre que un número determinado de obispos se reúnen para estudiar cuestiones determinadas se está haciendo realidad el significado del obispo como signo de comunión.

En nuestros días, y tras el concilio Vaticano II, una de las manifestaciones más extraordinarias de esa comunión es la Conferencia episcopal de una nación determinada. Aparte problemas de carácter técnico, todavía no resueltos, en particular su capacidad de movimiento en relación con el papa, 
las Conferencias episcopales están jugando un papel importante en nuestro mundo y son una bonita expresión del significado del obispo como agente de comunión al exterior de su iglesia. Si acaso falta la plasmación jurídica de la fuerza y obligatoriedad de sus decisiones, hay que reconocer su enorme valor moral. Por lo mismo, su importancia en la solución de problemas que afectan a una nación determinada.

No quiero cerrar este punto sin recoger algunos párrafos del Documento de Dombes sobre el Ministerio episcopal. Son verdaderamente extraordinarios y dibujan una preciosa imagen del obispo. Completan magníficamente el tema en cuestión.

"El ministerio del epíscopo, unido a su comunidad, asegura y significa con los otros ministerios «la dependencia de la iglesia respecto de Cristo, fuente de su misión y fundamento de su unidad» (Dombes, 1973, n.20). En la relación vivida en el seno de la iglesia con Cristo, Pastor soberano, la presencia del epíscopo recuerda a todos la prioridad de la iniciativa divina.

El epíscopo expresa la obediencia de la iglesia a Cristo en primer lugar por su propia sumisión a la Escritura, testimonio de la Palabra de Dios y herencia del ministerio de los Apóstoles. Es así como en la iglesia guarda el depósito de la fe contenido en la Escritura y preside la enseñanza. Sometido a la Escritura, el epíscopo ejerce su autoridad reguladora en la interpretación del mensaje evangélico a fin de conducir a la iglesia en la libertad y obediencia a Cristo, que nos ha dado el perfecto ejemplo de libertad y obediencia al Padre.

En el conjunto del colegio episcopal, como realidad una y universal, se expresa la sucesión ministerial del colegio original simbólico de los Doce, mientras que la totalidad de la iglesia sucede a este mismo colegio de los Doce, en cuanto simbolizaba y realizaba ya el Israel de la Nueva Alianza"57.

\section{4.- El episcopado como Ministerio universal}

Me encuentro en el final del camino. Mi estudio obedecía a una especie de manifiesto lanzado por el secretariado de FE y CONSTITUCIÓN del CEI. En dicho comunicado se decía que todas las iglesias, que forman el amplio abanico del Consejo Ecuménico de las Iglesias, tienen la intención de recuperar, en el caso de no tenerlo, el Ministerio episcopal como Ministerio

57. El ministerio episcopal. En Enchiridium Oecumenicum Y. Salamanca, 1986, nrs. 34,35,36. pp. 679-680. 
clave para su existencia. Al hacer la propuesta, expresaban una no pequeña reticencia. Decían: "Cada vez un mayor número de iglesias, que comprenden a las que participan en las negociaciones para la unión, se declaran dispuestas a ver en el episcopado un signo preeminente de la sucesión apostólica de toda la iglesia en la fe, en la vida y la doctrina; este hecho lo consideran como una realidad hacia la que hay que tender en el caso en que no existiera. La única cosa que considera incompatible con la investigación histórica y teológica contemporánea es la idea según la cual la sucesión episcopal sería idéntica a la apostolicidad de toda la iglesia y la contendría".

El mensaje, que se halla en el texto del Documento de Accra, es una buena noticia para la siempre deseada y, por desgracia, retardada unión de las iglesias. Las iglesias, que han hecho del episcopado su Ministerio principal, se ven confirmadas en esta decisión. Son, por lo demás, iglesias importantísimas. Entre ellas están la iglesia católico-romana, las iglesias ortodoxas y la iglesia anglicana.

Cierto que tales iglesias, en particular la iglesia católico-romana y las iglesias ortodoxas, deben ceder un tanto en su forma de acuñar teológicamente el Ministerio episcopal. En particular, en el tema de la sucesión apostólica. Estas iglesias han visto la sucesión episcopal como la única sucesión que hace posible hablar de la iglesia de Cristo. En el número $18 \mathrm{~b}$ de la Constitución sobre la iglesia dice el concilio Vaticano II: "Este santo Concilio, siguiendo las huellas del Vaticano I, enseña y declara con él que Jesucristo, eterno Pastor, edificó la santa iglesia enviando a sus apóstoles como Él mismo había sido enviado por el Padre (cf. Jn 20,21) y quiso que los sucesores de éstos, los obispos, hasta la consumación de los siglos, fuesen los pastores de su iglesia" 58 .

Si estas palabras conciliares se toman al pie de la letra, tal y como suenan, pocas esperanzas tienen de apostolicidad las iglesias que han abandonado el Ministerio epìscopal. El texto en cuestión nos dice bien claro que los obispos, sucesores de los apóstoles, deben ser por voluntad de Cristo los pastores de la iglesia hasta la consumación de los siglos. Por lo mismo, las iglesias, que han prescindido del episcopado, se han apartado de la voluntad de Cristo y así no pueden presentarse ante el mundo como iglesias suyas. Ésta parece ser la consecuencia lógica.

¿Qué se puede decir sobre el tema, si se tienen ante los ojos las investigaciones modernas? Pues que las cosas no son así de sencillas. El concilio Vaticano II hace una presentación reduccionista del tema. Y, por ello, debe

58. LG. $18 \mathrm{~b}$ 
ser interpretado no al pie de la letra, sino teniendo ante los ojos el enorme caudal histórico que hay en el tema. Sabemos que el Nuevo Tesmento habla de una enorme variedad de ministros. Las iglesias no tienen una configuración ministerial uniforme. El Ministerio episcopal no recibe la forma que hoy tiene en las iglesias sino tras un largo período de tiempo. Por ello, no puede ser considerado como una institución divina, si por ello se entiende que su existencia se debe a una voluntad expresa del Señor.

Al dato se refieren las palabras del número antes citado del Documento de Accra. Se nos dice taxativamente que "la única cosa que considera incompatible con la investigación histórica y teológica contemporánea es la idea según la cual la sucesión episcopal sería idéntica a la apostolicidad de toda la iglesia y la contendría" 59 . El aporte que, por lo demás se apoya en la historia y en la teología, según el Documento, responde a tales realidades. Por lo que las iglesias de tipo catolizante, es decir, las iglesias que han hecho del episcopado su Ministerio bandera deberán matizar su teología del mismo para responder mejor a lo que la investigación histórica y una buena teología nos dice del mismo.

El deseo expreso de recuperar el Ministerio episcopal por aquellas comunidades que no lo tienen, entre las cuales se encuentran todas las que forman el CEI, es una buena noticia para el logro de la unidad de las iglesias. Seguramente que también estas comunidades tendrán que hacer sus reajustes teológicos para hacer efectivo tal deseo. Puntos que, en ocasiones no aparecen claramente reflejados, deberán tener una presencia sin ambigüedades. Pienso, entre otros, en el carácter cristológico del Ministerio. Por mucha que sea la mediación de la iglesia en el tema, es decir, por mucho que se resalte el carácter eclesial del Ministerio, que es por lo demás un buen dato, no se puede olvidar que el Ministerio tiene también su carácter cristológico. En la evolución que ha sufrido hasta alcanzar las formas actuales, cosa que resaltan las iglesias salidas de la Reforma y además es cierta, Cristo ha tenido también su parte. Al fin y al cabo el Espíritu, que mueve a la iglesia, es el Espíritu de Cristo. Por lo mismo, el ministro obra, y obra conjuntamente, en nombre de Cristo y en nombre de la iglesia: in persona Christi et in persona ecclesiae.

Otro punto trascendental en el tema es el reconocimiento sin ambigüedades de la sacramentalidad de la ordenación. Los datos que ofrecen al respecto las cartas pastorales son elocuentes. "No descuides el carisma que hay en ti, que se te comunicó por intervención profética mediante la imposición

59. Nr. 37, p. 565 
de las manos del colegio de presbíteros" (1 Tim 4,14). "Por esto te recomiendo que reavives el carisma de Dios que está en ti por la imposición de mis manos" (2 Tim 1,6). Las expresiones son tan claras que no dejan lugar a dudas. Ellas hablan sin tapujos de un auténtico sacramento. Se dan, en efecto, todos los elementos necesarios para un sacramento. El Espíritu, el signo y la gracia. Es, por lo mismo, un acto de fidelidad teológica el reconocimiento de la sacramentalidad de la ordenación.

La oferta del Documento de Accra o, mejor la declaración, es indicadora de un camino que, según todos los indicios, gusta a todas las iglesias. Todos sabemos lo que significa el tema del Ministerio a la hora de pensar en la unidad de las iglesias. Al parecer la investigación sobre el Ministerio ha dado pasos de gigante hasta el extremo que ya no se puede considerar como obstáculo para la unidad. Los Institutos ecuménicos alemanes llegan a afirmar: "Dado que para un mutuo reconocimiento de los ministerios no existe ya ningún impedimento teológico decisivo, se ha superado un obstáculo importante para la plena comunidad en la Cena del Señor. Allí donde se dé una fe común en la presencia de Jesús en la eucaristía es posible una mutua admisión a la santa Cena"60.

Hace ya bastantes años que se escribieron estas palabras. Al leerlas, aparte el gozo que producen por el contenido que tienen, uno siente una enorme tristeza. El día de la unidad de las iglesias no parece estar cercano. Las palabras de Jesús en su oración solemne "Que todos sean uno. Como Tú, Padre, en mí y yo en ti, que ellos también sean uno en nosotros, para que el mundo crea que Tú me has enviado" (Jn 17,21) siguen ahí presentes. Se recuerdan por y en todas las iglesias, pero no acaban de dar su fruto. Y uno se pregunta: ¿por qué? Es verdad que hay ya un gran fondo de unidad. Es mucho más lo que nos une que lo que nos separa. Pero también es verdad que se da la división de las iglesias. A la hora de responder a la pregunta formulada, el desconcierto le invade a uno. En ocasiones la desunión tiene su base en privilegios que unas iglesias dicen tener frente a otras. Privilegios que casi siempre se teologizan. Con lo que se hacen más difíciles de superar. Este lenguaje choca con lo que los evangelios nos dicen del Señor. Después de recordar lo que sucede en el mundo, Jesús dice a sus discípulos: "pero no así entre vosotros, sino que el mayor entre vosotros sea como el menor y el que manda como el que sirve" (Lc 22,26). El mensaje del Señor, plasmado en este bello

60. Reforma y reconocimiento de los ministerios, Seminarios 57-58, Salamanca, 1975, nr. 23 , p. 553. 
texto, debe ser norma y guía de todo creyente en Él. Sobre todo, debe ser norma y guía de quienes tienen en la iglesia el Ministerio de la episkopé.

He recordado en este último apartado textos que ya habían sido citados en otros lugares. Lo que parece un tanto incongruente. Con todo, no hay que olvidar que este último punto es una síntesis del artículo. Esta condición pide la presencia de todo aquello que, de alguna manera, constituye el centro de la reflexión. Es el obsequio que hay que pagar a la exposición ordenada de un tema.

Termino el artículo con unas palabras del documento de Dombes: “Al final de esta nueva investigación no podríamos olvidar que nuestra meta es la reconciliación de los ministerios, indispensable para la reconstitución de la unidad visible actualmente rota. No pueden satisfacernos las evoluciones hacia un paralelismo en las instituciones. Estas deben tender al advenimiento de una sola episkopé en la iglesia una. De ello depende nuestra comunión plena"61.

P. BENITO DomíngueZ SÁNCHEZ

Valencia de D. Juan

León

61. El ministerio episcopal, En Enchiridium oecumenicu I, Salamanca, 1986, nr. 77, pp. $687-688$ 